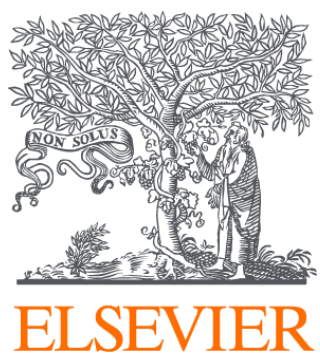

Since January 2020 Elsevier has created a COVID-19 resource centre with free information in English and Mandarin on the novel coronavirus COVID-

19. The COVID-19 resource centre is hosted on Elsevier Connect, the company's public news and information website.

Elsevier hereby grants permission to make all its COVID-19-related research that is available on the COVID-19 resource centre - including this research content - immediately available in PubMed Central and other publicly funded repositories, such as the WHO COVID database with rights for unrestricted research re-use and analyses in any form or by any means with acknowledgement of the original source. These permissions are granted for free by Elsevier for as long as the COVID-19 resource centre remains active. 


\title{
Banking research in the time of COVID-19
}

\author{
Allen N. Berger ${ }^{\text {a, * }}$, Asli Demirgüç-Kunt ${ }^{\text {b }}$ \\ ${ }^{a}$ University of South Carolina, Center for Financial Institutions at the Darla Moore School of Business, Wharton Financial Institutions Center, European Banking Center, \\ USA \\ ${ }^{\mathrm{b}}$ World Bank, USA
}

\section{A R T I C L E I N F O}

\section{JEL Classification:}

G01

G21

G28

Keywords:

Banks

Financial crises

COVID-19

Bailouts

Paycheck Protection Program

Global Financial Crisis

TARP

\begin{abstract}
A B S T R A C T
Despite the devastating worldwide human and economic tolls of the COVID-19 crisis, it has created some positive economic and financial surprises and opportunities for research. This paper highlights two such favorable surprises - the shortest U.S. recession on record and the avoidance of any banking crisis - and a number of research opportunities. The paper ties the "economic surprise" of the short recession to the speed and size of U.S. stimulus programs during COVID-19 - faster and larger than for the Global Financial Crisis (GFC). We connect the "financial surprise" of the resilient banking sector to prudential policies put in place during and after the GFC that fortified U.S. banks prior to COVID-19. These twin "surprises" are also mutually reinforcing - if either the economy or banking system had failed, so would the other. The paper also reviews extant COVID-19 banking research and suggest paths for future research. It recommends that particular attention be paid to research outside of the U.S. - where fewer favorable "surprises" may be present - as the best way to advance knowledge in this area.
\end{abstract}

\section{Introduction}

The human and economic tolls of COVID-19 have been devastating it has resulted in death and physical suffering for millions as well as recessions that caused significant economic damage. But grim as they are, crises often generate research opportunities, and the COVID-19 crisis is no exception. The economic destruction and research potential are similar in some ways to the Crash of 1929 and the ensuing Great Depression, and also the Global Financial Crisis of 2007-2009 (GFC) and the Great Recession it created.

However, in other ways, COVID-19 stands alone among economic crises. It features the most unanticipated large and widespread exogenous economic shock of all time - it was even more global than the GFC, affecting developed and developing nations alike. The pandemic caused recessions around the world, including one with the sharpest economic descent in U.S. recorded history. The crisis also elicited the fastest and largest set of policy responses of all time, with the U.S. government providing stimulus in the trillions very quickly. As discussed below, the crisis also engendered two outcomes in the U.S. that we characterize as very favorable "surprises" - the shortest recession of all time and the avoidance of any banking or other financial crisis. To be clear, the policies we refer to and the "surprising" outcomes we discuss here substantially pre-date the introduction of COVID-19 vaccinations. The ultimate economic and financial outcomes in the U.S. and other nations are yet to be determined as of the time of this writing. Nonetheless, to twist a phrase that is familiar to most crisis researchers from Reinhart and Rogoff (2009), and one that is also employed by Karakaplan (2021), this time really is different. Fortunately for all crisis and banking researchers, these unusual characteristics of COVID-19 are a significant source of opportunity to those wishing to research the crisis.

There are three main reasons why crises generally create so many research opportunities. First, the best way to learn what works in economics, finance, or any field of research is to study what happens when malfunctions occur, and crises are the epitome of what happens when

\footnotetext{
The authors thank Fari Moshirian and Tony Saunders for working with us on this topic, Iftekhar Hasan, editor and the anonymous editor and referees at the

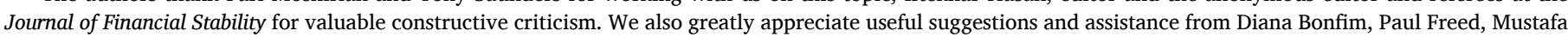

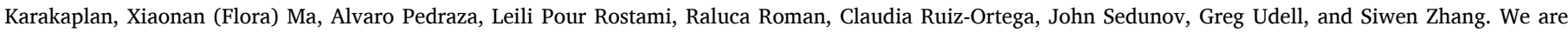

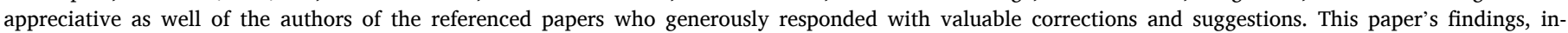

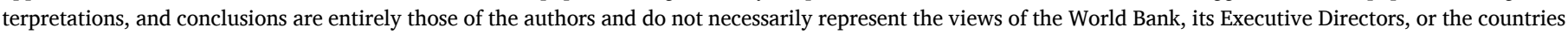
they represent.

* Corresponding author.

E-mail addresses: aberger@moore.sc.edu (A.N. Berger), ademirguckunt@worldbank.org (A. Demirgüç-Kunt).
} 
economies and markets do not function well. During economic and financial booms, almost every business strategy appears to be profitable, almost every financial investment seems to pay off, and almost every government policy appears to succeed. In fact, booms are when most of the important mistakes are made. The seeds of future crises are sown during booms, as institutional memory problems in remembering how to deal with past problems and other difficulties occur (e.g., Rajan, 1994; Berger and Udell, 2004; Thakor, 2005, 2015; Acharya and Naqvi, 2012; Berger and Bouwman, 2017). This concept is well exemplified in the banking context in remarks by former Federal Reserve Chairman Alan Greenspan, who argues that "the worst loans are made at the top of the business cycle" (Greenspan, 2001). The errors made during booms are revealed during crises, allowing researchers to differentiate between successful and unsuccessful business strategies, investments, and government policies.

Second, crises almost always bring about new government policies that generate numerous research papers assessing them. For example, the Troubled Asset Relief Program (TARP) bank bailout during the GFC brought about well over 100 new empirical research papers (e.g., see the "tree of knowledge" about this research in Berger and Roman, 2020, p. 175)). These studies investigate the determinants of which banks received the bailouts, the effects of the program on the recipient banks' valuations, and the effects of TARP on banking market discipline, banks' leverage risk, bank competition, credit supply, portfolio risks, and impacts on credit customers. In addition, some studies investigate the "big picture" issues of the extent to which TARP accomplished its two main goals of improving the real economy and reducing systemic risk. As will become clear, the Paycheck Protection Program (PPP) bailout of small businesses during COVID-19 is several times larger than TARP, has many times more participants, and involves a much greater financial stimulus as the funds are not paid back to the government as were the TARP bank bailout funds. It seems quite likely, given this comparison, that there will be many studies generated by PPP covering a wide variety of topics.

Finally, crises are sources of exogenous shocks that are employed as quasi-natural experiments to help address both existing and new research questions. To the extent that such shocks are plausibly exogenous - i.e., they affect the real economy or financial system, but are not themselves caused by economic or financial forces - they provide the best econometric identification possible. In banking research in particular, natural disaster and weather shocks, natural resource discoveries, and government policy innovations often provide quasi-natural experiments to study the impacts of banks on the real economy (see Berger et al., 2020a for a review). COVID-19 provides analogous versions of all three of these types of shocks. Disease outbreaks are similar to natural disaster and weather shocks. The introduction of vaccines to treat the pandemic is analogous to natural resource discoveries. Finally, the government policies that shut down economic activities to prevent spread of the virus and stimulus programs to counteract the economic damages caused by the crisis are examples of policy innovations. All of these different types of shocks are or likely will be employed as quasi-natural experiments to study the economic and financial outcomes of the crisis. Not all of these shocks are equally exogenous, but disease outbreaks were generally not predicted, and virtually no economic or financial actions were made in anticipation of these shocks, yielding very clean interpretation of the econometric results derived using these shocks.

We have already seen a large proliferation of research studies on economic and financial impacts, banking reactions, and policy choices during COVID-19. There are too many papers to cover thoroughly in one paper, and there is every reason to expect such research to continue for a long time to come. The Crash of 1929 and ensuing Great Depression resulted in over 50 years of great research. For example, it took about 30 years to discover the full role of the shrinkage of the money supply in causing and perpetuating the Great Depression (Friedman and Schwartz, 1963), and it required about 50 years to understand how the loss of bank credit supply resulting from bank failures during the crisis made the
Depression much worse (Bernanke, 1983). The research on the GFC and the Great Recession it generated has been ongoing for more than a decade and is still filling the journals as of this writing. The COVID-19 crisis, with all its unique characteristics, is likely to create a tidal wave of research papers for many years to come, and we hope that this paper may help perpetuate and improve this research.

It is also notable that a number of valuable research datasets are now available to research the COVID-19 crisis that were created for the purpose of monitoring the banks in the wake of the GFC. As examples, the Federal Reserve's Y14 A, Q, and M datasets provide detailed information on large banking organizations' projections of their conditions under a variety of macroeconomic scenarios; their asset classes and capital positions; and their loan portfolios; respectively. Some of these data have already been put to work in the research we review here, and we expect much more will be forthcoming in the next years.

Our main goals are to help understand the COVID-19 crisis and the resultant economic and financial research efforts as they relate to banking. We review, to the extent feasible, the extant research from the first year or so of past research. We focus most intently on how future banking research on this crisis can be improved, broadened, and deepened. We leverage considerably on the much larger banking research agenda from the GFC, which provides some useful directions where the COVID-19 research might fruitfully proceed.

As often occurs with banking and other economic and financial research, the extant research on COVID-19 reviewed here is heavily U.S.centric. To obtain a more complete picture of the impacts of the crisis and the policies that do or do not work well, we ask that future research become more broadly based to the extent possible. As explained below, this is especially important because many other nations are likely to be experiencing more difficulties with the crisis compared with the U.S.

Nevertheless, much of the attention in this article is on the U.S. case for several reasons. First, as noted, there is more research evidence for the U.S. than for other nations. Second, the economic, banking, and financial outcomes of the crisis for the U.S. are fairly well determined at this point in time. While the associated recession is over and there was no banking or financial crisis in the U.S., but the outcomes in the rest of the world are less certain. Third, the extraordinarily fast and large policy responses and favorable "surprises" in the U.S. provide excellent examples of what can be accomplished. Finally, by introducing these "surprises" as a key research topic, we hope to generate a flood of new econometric research on explaining them.

In this paper, we offer two major reasons for the "surprises" - the large and fast U.S. government stimulus programs initiated during the COVID-19 crisis and the long-term prudential policies from the GFC that prepared U.S. banks for a future crisis. However, we leave the econometric research to support or reject these reasons as an opportunity for future researchers.

Thus, our extra attention on the U.S. case is designed for maximum impact based on what we currently know. We also suggest that focus in future research on other developed and developing nations may well be even more fruitful.

The remainder of this paper is organized as follows. Section 2 places the COVID-19 crisis in context by comparing it to the GFC. While both crises caused significant economic harm and have other similarities, we highlight the key distinctions of the two "surprises" of COVID-19. Section 3 briefly discusses the "economic surprise" of the short recession and fast turnaround in the U.S. economy long before the vaccines were available. Section 4 documents the "financial surprise" in the banking industry, focusing primarily on regulatory accounting data, and backing up our conclusions with some market data. Sections 5 and 6 discuss one key reason each for the two "surprises" - government stimulus programs during COVID-19 for the "economic surprise" and bank prudential policy responses to the GFC for the "financial surprise." We primarily cover just one COVID-19 stimulus program in Section 5 for brevity, comparing the Paycheck Protection Program (PPP) to the Troubled Asset Relief Program (TARP) from the GFC. In Section 6, we describe and 
discuss research on four different methods of strengthening prudential policies in response to the GFC - higher capital requirements, introduction of stress tests, increased microprudential supervisory scrutiny, and shift to the Orderly Liquidation Authority (OLA) bail-in regime. Section 7 goes beyond the simplistic "surprises" and the key reasons behind them and discusses some of the interactions among them. Finally, Section 8 concludes by suggesting some additional directions for future research.

\section{Putting the COVID-19 crisis in context - a comparison with the GFC}

The COVID-19 crisis may be best understood by explaining how different it is from other crises. We focus particularly on differences from the GFC. This was also a very large international crisis and caused the most economic and financial harm since the Great Depression. The two "surprises" of the COVID-19 crisis are key distinctions from the GFC. In the interest of brevity, we keep the references to the research literature to a minimum in this background section.

\subsection{The GFC}

The GFC was a banking crisis - a financial crisis that originated in the banking sector - that lasted about 10 quarters in the U.S. from 2007: Q3-2009:Q4 (Berger and Bouwman, 2013). ${ }^{1}$ It also begat an economic crisis known as the Great Recession, that lasted 18 months from December 2007 to June 2009 according to the National Bureau of Economic Research (NBER). The crisis started with the toxic mix that often brings about financial crises - lowered credit standards, misunderstood financial innovations, failure to diversify, and excessive leverage.

The GFC involved a lowering of credit standards during a boom, which often occurs, as lenders lose institutional memory of past credit lessons as discussed above. In this case, the banks expanded credit availability at relatively low interest rates to subprime mortgage borrowers. This practice appears to have been based on a faulty assumption that housing prices would almost surely continue to rapidly rise, so that the subprime borrowers would be able to refinance without necessarily having sufficient income or other means to make the regular mortgage payments.

The misunderstood financial innovations included the mortgagebacked securities (MBS) and other structured finance products built on subprime mortgages. The future payment flows from these mortgages were often sliced and diced multiple times to extract additional highly rated securities that were difficult to value. These securities caused massive capital losses and illiquidity when the housing price boom that underlaid the value of these securities ended, creating losses, uncertainty, and market freezes.

The lack of diversification occurred in many financial entities, including commercial banks and investment banks. Many, if not most U. S. commercial banks had very significant portions of their loan portfolios in residential and commercial real estate, and some also packaged and held MBS and other securities based on mortgages. Some investment banks also engaged actively in packaging securities based on mortgages, which resulted in these firms also holding large inventories of these hard-to-value securities. In the cases of Bear Stearns and Lehman Brothers, the results were disastrous.

High leverage was widespread in the U.S. leading up to the GFC,

\footnotetext{
${ }^{1}$ These are unofficial dates for the U.S. as established in one research paper, as we are unaware of any official dating of financial crises. Other researchers also date the financial crisis in the U.S. as ending in June 2009 when the recession ended. Some distinguish the European Sovereign Debt Crisis that continued for several years as a separate crisis, while others think of it as part of the GFC.
}

from households to firms to financial institutions. Between 2000 and 2008 , household debt approximately doubled from $\$ 7.2$ trillion to $\$ 14.1$ trillion, while debt in the financial sector more than doubled from $\$ 8.7$ trillion to $\$ 18$ trillion according to Federal Reserve data. ${ }^{2}$ Some of the investment banks were leveraged on the order of 30:1, so a three percent portfolio loss could potentially destroy their net worth.

A key event that triggered the GFC was the reduction in housing prices that started in 2006, which created losses on MBS and related securities, as well as questions about how to value them. By August 2007 , losses of confidence and freezes impaired the operations of these and other financial markets. Issues in the interbank lending market and syndicated loan market created liquidity problems for some banks that could no longer easily borrow or sell portions of the loans they originated. These problems worsened considerably after a number of financial institutions failed or needed rescues, including Bear Stearns, Indy Mac, Countrywide, and finally Lehman Brothers, which declared bankruptcy in September 2008. The public became well aware of the problems associated with mortgages and the securities based on them, and public confidence eroded.

The commercial banks suffered liquidity problems from the market freezes and capital losses on their mortgages and securities based on mortgages, resulting in significantly reduced credit supplies. These reduced credit supplies were key factors in initiating the Great Recession.

The GFC was very costly in terms of reduced real economic output during the 10-quarter recession and slow recovery thereafter, as well as losses of household wealth, and the significant number of failures of financial institutions, particularly the large ones noted above with substantial franchise values. The many government interventions, most of which we do not have space to discuss in depth, also imposed costs on taxpayers. While there are many estimates of the cost of the crisis, we just briefly mention estimates from two papers. Atkinson et al. (2013) estimate at least $\$ 6$ trillion to $\$ 14$ trillion of foregone real economic output or 40-90\% of one year's GDP plus a loss of financial wealth of an estimated $\$ 16$ trillion, or $24 \%$ of household net worth. Lucas (2019) derives an estimate of the costs all of the U.S. bailouts during the GFC including TARP, Fannie Mae, Freddie Mac, and a number of others - of about $\$ 500$ billion or $3.5 \%$ of a year's GDP based on a theoretical framework.

\subsection{The COVID-19 crisis}

The COVID-19 crisis stands in sharp contrast to the GFC. COVID-19 was not a banking crisis. It did not start from financial issues involving credit standards, financial innovations, lack of diversification, or excessive leverage. The direction of causation was not from banking issues to problems in the real economy. However, like the GFC, COVID19 did involve very significant government intervention costs - much higher in fact.

COVID-19 had its origins as a public health crisis and became an economic crisis as the economy shut down to mitigate the spread of the virus. Theoretically, it could have become a banking crisis as well, but did not. Consumers reduced their demand for goods and services involving personal contact to avoid the disease. Economic supply also contracted as workers and their employers shut down places of business involving personal contact. Government restrictions or lockdowns on businesses, schools, travel, etc. further reduced economic supply, and those not working also reduced demand due to lower incomes in many cases. Small businesses and their employees generally suffered significantly more than large businesses and their workers. Many small firms suffered large decreases in demand, were unable to organize work

\footnotetext{
${ }^{2}$ https://www.wsj.com/articles/from-dutch-tulips-to-internet-stocks-bubbles-often-burst-11620379809?st=6lbwxzg8iuywthu\&reflink=article_email_ share
} 
remotely using technology, and did not have sufficient room for social distancing. ${ }^{3}$ Those in certain industries, such as hospitality and construction were particularly hard hit (e.g., Chen and Yeh, 2020), as were those in states with the strictest lockdowns (e.g., Goel and Thakor, 2020; Hale et al., 2020). As discussed further in Section 3, there was an "economic surprise" in which the recession caused by the public health crisis was very short and the economic recovery was quite extraordinary.

Banks were also affected by COVID-19, primarily through the difficulties of their borrowers. There were justifiable fears that problems in the real economy could have resulted in significant numbers of bank failures and a financial crisis. Bank capital could have been depleted by loan losses from businesses and households that could not repay their loans. As a precaution against this, the Federal Reserve announced in June 2020 that they would cap dividends and ban stock buybacks by the large banks, and reversed this only in December 2020. As discussed in more detail in Section 4, there was a "financial surprise" in which there was no banking crisis in the U.S., nor any discernable widespread financial distress in the industry. ${ }^{4}$

The COVID-19 effects on the economy and the banking system occurred as a result of national and local public health shocks and government activity restrictions shocks. All of these shocks may be considered as exogenous to the firms, households, and banks, i.e., not significantly caused by or easily anticipated in advance by any of these economic agents. A number of measures of these shocks are readily available at the national and state levels from several publicly available sources. These are quite useful both for research and for us to discuss the crisis. $^{5}$

We focus on these shocks during the first half of 2020, which is when most of the economic damage of the crisis occurred. The public health shocks in the U.S. commenced when the first COVID-19 case was identified on January 21, 2020, and the first government activity restrictions shock in the country started on February 29, 2020, when the Governor of the State of Washington declared a state of emergency.

Berger et al. (2021a) provide an illustration of how these shocks are employed in research, and their data help us navigate the first months of the crisis. They construct 14 different COVID-19 shocks from the raw data. Their public health shocks include new and total COVID-19 cases and deaths at the national and state levels, and their government activity restrictions indices include totals of stay-at-home orders, business shutdown orders or limitations, quarantines, etc. at the national and state levels. The rich variation in COVID-19 shocks across the different measures allows us to see how the crisis unfolded at different rates across the nation and helps enable the precision and robustness of research on the COVID-19 crisis. Studies of the GFC and earlier crises often just compare effects during a crisis versus normal times and do not have access to such detailed exogenous shock data.

We first consider here one of the public health shocks, new disease cases per $100,000(100 \mathrm{~K})$ population. National new cases per $100 \mathrm{~K}$ population intensified considerably over time from much less than one at the end of January and February to 5.84, 8.80, 6.41, and 12.60 at the

\footnotetext{
${ }^{3}$ Humphries et al. (2020) report that $60 \%$ of small businesses had laid off at least one worker by March 2020, and the Wall Street Journal chronicles that about 200,000 failed during the first year of the pandemic (https://www.wsj. com/articles/small-businesses-on-one-chicago-street-strug-

gle-to-meet-demand-as-covid-19-restrictions-end-11624267802). One study suggests that some firms can benefit from "hibernation," reducing expenses to the minimum necessary to withstand the pandemic, and using credit to remain viable until the crisis subsides (Didier et al., 2021).

${ }^{4}$ Stock markets also suffered some short-term losses that were more than reversed by mid-2021, but our main financial focus in this article is on banking, rather than financial markets generally.

5 Examples include the Economic Tracker of Chetty et al. (2020); the Johns Hopkins Coronavirus Resource Center; and the University of Washington COVID-19 Policies Database from Adolph et al. (2021).
}

end of March, April, May and June, respectively. The distributions across states show considerably more variation over space and time. New York State was the epicenter of cases at the end of March, with 37.1 reported cases per $100 \mathrm{~K}$ - more than six times the national average. New York State had fewer cases in subsequent months, with Arizona having the highest number of new infections at the end of June with 41.2 per $100 \mathrm{~K}$.

We next consider the authors' index of government activity restrictions, a sum of various constraints on activities that ranges from zero to 10 . The national average was exactly zero at the end of January and only 0.023 at the end of February with a single restriction in Washington State at that time. The national average across states rose to 6.85 at the end of March, peaked at 7.56 at the end of April, and fell slightly by the ends of May and June to 6.78 and 6.41, respectively. There was not as much variation across states in the restrictions as there was in the infections reported just above. Individual states hit maximums of 10 at the ends of March and April, with the maximums falling to nine and eight at the ends of May and June, respectively.

Not surprisingly, public health and government restrictions shocks had devastating effects on the U.S. economy. A recession was underway by late February and conditions worsened until April. The seasonally adjusted U.S. unemployment rate increased from 3.5\% in January and February 2020, the lowest rate in many decades, to $4.4 \%$ in March to $14.8 \%$ in April, the highest rate since the Great Depression. ${ }^{6}$ Real U.S. GDP, which is measured in quarters, declined at an annualized rate of $5.0 \%$ in 2020:Q1 and a record rate of $31.4 \%$ in 2020:Q2. ${ }^{7}$ The economic decline was quite widespread - every state had an annualized rate decline of real GDP in 2020:Q2 of at least $20 \%{ }^{8}$ The lowest rate occurred in Washington, DC (which we consider as a state for our purposes) with a $20.4 \%$ decline, likely due to steady federal employment. The greatest percentage declines were more than twice as high at $42.2 \%$ each for Nevada and Hawaii, likely due reliance on travel and tourism, which was effectively shut down.

Despite the dramatic short-term increases in unemployment and declines in real output, an "economic surprise" soon appeared as the economy turned around, and a "financial surprise" appeared in the form of a resilient banking industry. We complete the story of the COVID-19 crisis by discussing these "surprises" in the next two sections.

\section{The U.S. "economic surprise" during the COVID-19 crisis}

After the devastating start to the recession in February 2020 as reported above - unemployment rate increases in March and April and large drop in real GDP in 2020:Q2 - the U.S. economy improved significantly very quickly. The unemployment rate dropped steadily after the April high of $14.8 \%$ down to $6.9 \%$ by October, and reached $6.1 \%$ by April 2021. Real U.S. GDP grew at an astounding annualized

\footnotetext{
${ }^{6}$ https://fred.stlouisfed.org/series/UNRATE

7 The annualized rate of decline of $31.4 \%$ amounts to about an $8 \%$ decline in the quarter. https://fred.stlouisfed.org/graph/fredgraph.xls?bgcolor $=\%$ 23e1e9f0\&chart_type $=$ line $\&$ drp $=0 \&$ fo $=$ open $\% 20$ sans \& graph_bgcolor $=\%$ $23 \mathrm{ffffff} \&$ height $=450 \&$ mode $=$ fred \&recession_bars $=$ on $\&$ txtcolor $=\%$ $23444444 \&$ ts $=12 \&$ tts $=12 \&$ width $=412 \&$ nt $=0 \&$ thu $=0 \&$ trc $=0 \&$ show_legend $=$ yes\&show_axis_titles $=$ yes \&show_tool-

tip=yes\&id=A191RL1Q225SBEA\&scale =left\&cosd=1947-04-01\&coed$=2021-01-01 \&$ line_color $=\% 234572$ a7\&link_values $=$ false $\&$ line_style $=$ solid $\&$ mark_type-

$=$ none $\& \mathrm{mw}=3 \& \mathrm{lw}=2 \&$ ost $=-99999 \&$ oet $=99999 \& \mathrm{mma}=0 \& \mathrm{fml}=\mathrm{a} \& \mathrm{fq}=\mathrm{Quar}-$ terly $\&$ fam $=$ avg $\&$ fgst $=$ lin $\&$ fgsnd $=2020-02-01 \&$ line_index-

$=1 \&$ transformation $=$ lin $\&$ vintage_date $=2021-05-27 \&$ revision date $=2021-05-27 \&$ nd $=1947-04-01$

8 https://www.bea.gov/news/2020/gross-domestic-product-state-2ndquarter-2020
} 
rate of $33.4 \%$ in $2020: Q 3$, with increases across the states ranging from a minimum of $19.2 \%$ in Washington, DC to a maximum of $52.2 \%$ in Nevada. ${ }^{9}$ Increases continued at the national level at $4.3 \%$ and $6.4 \%$ annualized rates in 2020:Q4 and 2021:Q1, respectively. Some analysts are so optimistic that they now predict that by the end of 2021, the U.S. economy will have fully recovered to the point at which it would have been had the crisis never occurred. ${ }^{10}$

The turnaround that began in April 2020 was officially acknowledged on July 19, 2021, when the National Bureau of Economic Research (NBER), the arbiter of recessions, officially declared that the U. S. recession ended in April 2020. ${ }^{11}$ The 2-month duration make it the shortest recession in U.S. history, just one-third as long as the 6-month 1980 recession, the prior shortest on record since $1854 .^{12}$

During the recession as economic output fell, personal incomes of many Americans actually rose, and debt loads lightened due to government stimulus programs providing additional income. Research suggests that government policies during the pandemic led poverty rates to fall and low percentiles of income to rise across a range of demographic groups and geographies (e.g., Han et al., 2020). An Experian report suggests that the average consumer credit scores increased significantly in 2020 , mostly driven by a significant reduction in the number of consumers with subprime designation (Lembo Stolla, 2021). Credit card balances reported in the G.19 Consumer Credit statistical release fell by a very large annualized rate of $32 \%$ by $2020: Q 2$ (Adams and Bord, 2020). The Wall Street Journal reports that most Americans got richer during the first year of the pandemic owing to fiscal and monetary stimulus, as well as stock and housing market booms. ${ }^{13}$

The fates of small businesses - which often are the key income sources for the proprietors and employees that operate them - were not as bleak as first predicted. While many businesses failed during the COVID-19 crisis as discussed above, one study using Bureau of Labor Statistics data comparisons over time suggests that business exits were much less severe than were expected early in the crisis, likely due to swiftly enacted government policies (Crane et al., 2021).

Thus, we argue that the swift, widespread, and relatively quickly acknowledged turnarounds in GDP growth and unemployment rates and employment, as well as the improvements in personal incomes, poverty rates, credit scores, consumer debt, and business exits clearly describe a favorable "economic surprise." To be sure, the U.S. economy may not be completely out of the woods as of this writing in mid-2021. Supply bottlenecks, the withdrawal of economic and monetary stimuli, and most importantly the spread of the very infectious Delta variant could still lead to a deceleration and undermine recovery. However, we argue that the ultra-fast economic recovery to date qualifies as the "economic surprise" of this crisis.

\section{The U.S. banking "surprise" during the COVID-19 crisis}

The very steep slide in the U.S. and global economies during COVID19 might have been expected to result rapidly in banking crises due to large credit losses and uncertainty about future prospects. However, more than a year later, we are surprisingly unaware of banking crises to date anywhere in the world, although there are areas of significant concern (e.g., OECD, 2021).

\footnotetext{
9 https://www.bea.gov/news/2020/gross-domestic-product-state-3rdquarter-2020

${ }^{10}$ https://www.wsj.com/articles/the-economic-recovery-is-here-reboundjobs-stock-market-unemployment-biden-aid-package-11622642152

11 https://www.nber.org/news/business-cycle-dating-committee-announcement-july-19-2021

12 https://earlyretirementnow.com/2020/08/25/the-shortest-recession-evermy-thoughts-on-the-state-of-the-economy/

13 https://www.wsj.com/articles/during-covid-19-most-americans-got-richerespecially-the-rich-11624791602).
}

In this section, we dig deeper to explore the impact on the U.S. banking system primarily using raw data from regulatory Call Reports from 2019:Q4 to 2020:Q4, as well as other information. What we see supports our claim of a favorable "financial surprise" for the U.S. banking system during the COVID-19 crisis. Not only was there no banking crisis, but the banks performed very well and did not suffer any noticeable financial distress.

This is not an econometric analysis, but a rough look at how the industry performed during some very volatile economic circumstances from before the crisis to well into the economic recovery. We find no evidence of problems in multiple statistics for bank conditions, credit performance, or portfolio allocations across any of the eight financial ratios examined for the distribution of all banks or for the distribution of large, systemically important banks.

Before proceeding, however, we provide three caveats regarding the regulatory accounting data due to easing actions by U.S. regulators and supervisors, and how they may affect our analysis. First, regulators made a number of changes to how the Basel III regulatory capital ratios were computed during the crisis to make it easier for banks to meet the requirements. For this reason, we view these regulatory capital ratios as potentially less informative during the crisis and exclude them from consideration. We focus attention instead only on a non-regulatory equity capital ratio that is measured consistently over time.

Second, supervisors allowed for forbearance of missed or late payments on some debt, which may affect the accuracy of our calculation of the nonperforming loans ratio based on credits that are past due at least 90 days or in nonaccrual status and/or charge-offs on these loans. While we keep these figures, we view them with additional caution and also include a ratio for loan and lease loss allowances, which should reveal whether banks are keeping sufficient reserves for eventual losses on these loans.

Third, supervisors temporarily reduced focus on bank examinations, which could result in some institutions taking advantage of lessened oversight and reporting inaccurately favorable Call Report data. While we do not expect substantial inaccuracies to occur as a result, this could affect the books of a small number of banks, and so we recommend overall caution in interpreting the data. Thus, while the statistics we report may be imperfect, they are the best that we have available and they tell a very consistent story.

As a further caveat, we certainly cannot claim that there will be no banking crises or other financial distress in the near future in the U.S. There are plenty of economic dislocations, inflationary fears, and frothy financial markets that resulted from the crisis and some of the policies to deal with it, that have the potential to create near-term banking problems. Nonetheless, the facts that the year 2020 went by without any significant financial distress reflected in the regulatory accounting data in the U.S. banking industry, that the limited information on stock market values suggest that the industry is now more valuable than before the crisis, and that systemic risk is measured as lower than before the pandemic qualifies as a favorable "financial surprise" in our view.

After our presentation of the accounting data in Section 4.1, we provide a few additional statistics that do not depend on accounting data to bolster our claims in Section 4.2. We briefly offer some more sobering thoughts for banking conditions in the remainder of the world in Section 4.3, and provide some suggestions for future research in Section 4.4.

\subsection{U.S. banking data from 2019:Q4 to 2020:Q4}

Table 1 provides quarter-by-quarter snapshots of the U.S. banking system from 2019:Q4 to 2020:Q4 from the regulatory Call Reports, showing several dimensions of bank performance. Thus, we cover the industry from the quarter before COVID-19 struck in the U.S. in 2019: Q4, to the quarter containing the economic peak in 2020:Q1, to the quarter with the recession trough of 2020:Q2, to the two subsequent quarters of recovery, 2020:Q3 and 2020:Q4.

For each quarter, we show summary statistics for eight ratios of 
Table 1

Summary statistics of bank conditions, credit performance, and portfolio allocations for the U.S. banking industry and U.S. G-SIBs over 2019:Q4 to 2020:Q4.

\begin{tabular}{|c|c|c|c|c|c|c|c|c|c|c|c|c|c|c|}
\hline \multirow[b]{2}{*}{ Panel A - 2019: Q4 } & \multicolumn{8}{|c|}{ All banks } & \multicolumn{6}{|c|}{ G-SIBs } \\
\hline & & & & & & & & & & & & & & \\
\hline & $\mathrm{N}$ & Mean & SD & $\mathrm{P} 10$ & P25 & P50 & P75 & P90 & $\mathrm{N}$ & Mean & SD & Min & P50 & $\operatorname{Max}$ \\
\hline \multicolumn{15}{|l|}{ Bank Conditions } \\
\hline Equity/GTA & 5227 & 13.41 & 10.24 & 8.98 & 9.96 & 11.37 & 13.45 & 16.81 & 8 & 10.54 & 1.27 & 8.35 & 10.49 & 12.77 \\
\hline Cash, Due from, and Securities/GTA & 5227 & 30.33 & 17.53 & 12.69 & 17.70 & 25.79 & 38.76 & 54.59 & 8 & 47.71 & 18.93 & 28.03 & 39.49 & 81.91 \\
\hline \multicolumn{15}{|l|}{ Bank Credit Performance } \\
\hline Charge-offs/GTA & 5227 & 0.14 & 0.40 & 0.00 & 0.01 & 0.05 & 0.13 & 0.31 & 8 & 0.20 & 0.19 & 0.00 & 0.22 & 0.55 \\
\hline Nonperforming Loans/GTA & 5227 & 0.61 & 0.98 & 0.00 & 0.09 & 0.34 & 0.76 & 1.42 & 8 & 0.31 & 0.24 & 0.00 & 0.33 & 0.78 \\
\hline Loan and Lease Losses Allowance/GTA & 5227 & 0.81 & 0.51 & 0.36 & 0.57 & 0.77 & 0.98 & 1.23 & 8 & 0.36 & 0.27 & 0.03 & 0.42 & 0.75 \\
\hline \multicolumn{15}{|l|}{ Bank Portfolio Allocations } \\
\hline Loans/GTA & 5227 & 64.48 & 17.74 & 40.99 & 56.27 & 68.76 & 76.81 & 82.45 & 8 & 36.80 & 17.83 & 8.07 & 42.90 & 54.80 \\
\hline Unused Commitment/GTA & 5227 & 22.98 & 448.69 & 2.36 & 5.41 & 9.53 & 14.34 & 19.60 & 8 & 42.35 & 19.68 & 12.26 & 48.48 & 69.29 \\
\hline Deposits/GTA & 5227 & 81.33 & 12.07 & 74.47 & 79.69 & 83.98 & 86.88 & 88.71 & 8 & 78.18 & 5.52 & 70.21 & 78.86 & 85.31 \\
\hline \multicolumn{15}{|l|}{ Panel B - 2020: Q1 } \\
\hline & $\mathrm{N}$ & Mean & SD & $\mathrm{P} 10$ & P25 & P50 & P75 & P90 & $\mathrm{N}$ & Mean & SD & Min & P50 & Max \\
\hline \multicolumn{15}{|l|}{ Bank Conditions } \\
\hline Equity/GTA & 5165 & 13.31 & 10.26 & 8.93 & 9.88 & 11.29 & 13.31 & 16.67 & 8 & 9.13 & 1.47 & 6.96 & 9.31 & 11.51 \\
\hline Cash, Due from, and Securities/GTA & 5165 & 30.99 & 17.45 & 13.29 & 18.41 & 26.70 & 39.34 & 55.23 & 8 & 49.88 & 20.07 & 28.84 & 41.54 & 82.55 \\
\hline \multicolumn{15}{|l|}{ Bank Credit Performance } \\
\hline Charge-offs/GTA & 5165 & 0.03 & 0.11 & 0.00 & 0.00 & 0.00 & 0.02 & 0.06 & 8 & 0.05 & 0.04 & 0.00 & 0.05 & 0.13 \\
\hline Nonperforming Loans/GTA & 5165 & 0.65 & 1.07 & 0.00 & 0.10 & 0.36 & 0.81 & 1.51 & 8 & 0.31 & 0.24 & 0.00 & 0.31 & 0.78 \\
\hline Loan and Lease Losses Allowance/GTA & 5165 & 0.84 & 0.56 & 0.38 & 0.59 & 0.79 & 1.00 & 1.26 & 8 & 0.54 & 0.41 & 0.03 & 0.68 & 1.13 \\
\hline Bank Portfolio Allocations & & & & & & & & & & & & & & \\
\hline Loans/GTA & 5165 & 63.82 & 17.66 & 40.71 & 55.75 & 67.99 & 76.29 & 81.58 & 8 & 35.75 & 17.68 & 8.34 & 41.26 & 55.39 \\
\hline Unused Commitment/GTA & 5165 & 23.08 & 440.76 & 2.45 & 5.53 & 9.69 & 14.67 & 19.85 & 8 & 36.31 & 16.54 & 8.62 & 38.35 & 60.20 \\
\hline Deposits/GTA & 5165 & 81.10 & 12.16 & 73.60 & 79.29 & 83.85 & 86.85 & 88.72 & 8 & 78.09 & 7.23 & 70.16 & 77.44 & 87.40 \\
\hline Panel C - 2020: Q2 & & & & & & & & & & & & & & \\
\hline & $\mathrm{N}$ & Mean & SD & $\mathrm{P} 10$ & P25 & P50 & P75 & P90 & $\mathrm{N}$ & Mean & SD & Min & P50 & Max \\
\hline Bank Conditions & & & & & & & & & & & & & & \\
\hline Equity/GTA & 5113 & 12.63 & 9.99 & 8.30 & 9.27 & 10.70 & 12.69 & 15.98 & 8 & 9.35 & 0.75 & 7.96 & 9.29 & 10.29 \\
\hline Cash, Due from, and Securities/GTA & 5113 & 32.25 & 17.20 & 14.18 & 19.77 & 28.69 & 40.68 & 55.60 & 8 & 53.38 & 17.26 & 35.33 & 46.72 & 83.43 \\
\hline Bank Credit Performance & & & & & & & & & & & & & & \\
\hline Charge-offs/GTA & 5113 & 0.06 & 0.20 & 0.00 & 0.00 & 0.01 & 0.04 & 0.12 & 8 & 0.10 & 0.09 & 0.00 & 0.13 & 0.27 \\
\hline Nonperforming Loans/GTA & 5113 & 0.61 & 1.00 & 0.00 & 0.09 & 0.34 & 0.78 & 1.41 & 8 & 0.42 & 0.35 & 0.00 & 0.40 & 1.02 \\
\hline Loan and Lease Losses Allowance/GTA & 5113 & 0.82 & 0.56 & 0.37 & 0.58 & 0.77 & 0.97 & 1.22 & 8 & 0.72 & 0.52 & 0.05 & 0.89 & 1.43 \\
\hline Bank Portfolio Allocations & & & & & & & & & & & & & & \\
\hline Loans/GTA & 5113 & 62.95 & 17.47 & 40.28 & 54.73 & 66.76 & 75.22 & 80.93 & 8 & 32.73 & 15.93 & 7.64 & 37.08 & 51.33 \\
\hline Unused Commitment/GTA & 5113 & 23.18 & 470.95 & 2.28 & 5.30 & 9.16 & 13.56 & 18.29 & 8 & 36.44 & 16.80 & 11.96 & 42.18 & 61.46 \\
\hline Deposits/GTA & 5113 & 81.13 & 12.27 & 73.35 & 79.38 & 83.83 & 87.10 & 88.98 & 8 & 79.96 & 5.90 & 71.86 & 79.98 & 88.16 \\
\hline Panel D - 2020: Q3 & & & & & & & & & & & & & & \\
\hline & $\mathrm{N}$ & Mean & SD & $\mathrm{P} 10$ & P25 & $\mathrm{P} 50$ & P75 & P90 & $\mathrm{N}$ & Mean & SD & Min & P50 & $\operatorname{Max}$ \\
\hline Bank Conditions & & & & & & & & & & & & & & \\
\hline Equity/GTA & 5082 & 12.69 & 10.00 & 8.32 & 9.32 & 10.79 & 12.79 & 15.97 & 8 & 9.60 & 0.75 & 8.32 & 9.71 & 10.65 \\
\hline Cash, Due from, and Securities/GTA & 5082 & 32.58 & 17.34 & 14.03 & 19.98 & 29.17 & 41.18 & 56.13 & 8 & 54.39 & 15.90 & 39.14 & 47.81 & 83.57 \\
\hline Bank Credit Performance & & & & & & & & & & & & & & \\
\hline Charge-offs/GTA & 5082 & 0.08 & 0.28 & 0.00 & 0.00 & 0.02 & 0.07 & 0.18 & 8 & 0.15 & 0.13 & 0.00 & 0.19 & 0.39 \\
\hline Nonperforming Loans/GTA & 5082 & 0.59 & 1.02 & 0.00 & 0.08 & 0.32 & 0.74 & 1.37 & 8 & 0.43 & 0.38 & 0.00 & 0.37 & 1.15 \\
\hline Loan and Lease Losses Allowance/GTA & 5082 & 0.83 & 0.57 & 0.38 & 0.59 & 0.79 & 1.00 & 1.25 & 8 & 0.72 & 0.50 & 0.05 & 0.87 & 1.39 \\
\hline Bank Portfolio Allocations & & & & & & & & & & & & & & \\
\hline Loans/GTA & 5082 & 62.61 & 17.60 & 39.81 & 54.20 & 66.10 & 74.99 & 81.29 & 8 & 32.21 & 15.72 & 7.32 & 36.29 & 51.58 \\
\hline Unused Commitment/GTA & 5082 & 21.17 & 399.66 & 2.40 & 5.25 & 9.22 & 13.97 & 18.78 & 8 & 36.90 & 16.86 & 12.55 & 41.51 & 61.25 \\
\hline Deposits/GTA & 5082 & 81.27 & 12.30 & 73.41 & 79.58 & 84.02 & 87.12 & 89.05 & 8 & 80.37 & 5.55 & 72.58 & 80.49 & 88.38 \\
\hline Panel E - 2020: Q4 & & & & & & & & & & & & & & \\
\hline & $\mathrm{N}$ & Mean & SD & $\mathrm{P} 10$ & P25 & P50 & P75 & $\mathrm{P} 90$ & $\mathrm{~N}$ & Mean & SD & Min & P50 & Max \\
\hline Bank Conditions & & & & & & & & & & & & & & \\
\hline Equity/GTA & 5050 & 12.56 & 9.93 & 8.36 & 9.28 & 10.65 & 12.62 & 15.63 & 8 & 9.27 & 1.01 & 7.56 & 9.51 & 10.95 \\
\hline Cash, Due from, and Securities/GTA & 5050 & 35.27 & 17.34 & 15.84 & 22.72 & 32.28 & 45.02 & 58.70 & 8 & 55.13 & 16.48 & 38.83 & 49.15 & 84.47 \\
\hline Bank Credit Performance & & & & & & & & & & & & & & \\
\hline Charge-offs/GTA & 5050 & 0.11 & 0.34 & 0.00 & 0.00 & 0.03 & 0.11 & 0.25 & 8 & 0.19 & 0.16 & 0.00 & 0.23 & 0.49 \\
\hline Nonperforming Loans/GTA & 5050 & 0.54 & 0.97 & 0.00 & 0.07 & 0.29 & 0.68 & 1.25 & 8 & 0.41 & 0.36 & 0.00 & 0.36 & 0.96 \\
\hline Loan and Lease Losses Allowance/GTA & 5050 & 0.83 & 0.55 & 0.37 & 0.58 & 0.79 & 1.01 & 1.25 & 8 & 0.68 & 0.48 & 0.04 & 0.87 & 1.31 \\
\hline Bank Portfolio Allocations & & & & & & & & & & & & & & \\
\hline Loans/GTA & 5050 & 60.01 & 17.52 & 37.78 & 50.81 & 62.93 & 72.51 & 79.15 & 8 & 31.49 & 15.45 & 6.62 & 36.35 & 49.84 \\
\hline Unused Commitment/GTA & 5050 & 21.06 & 394.28 & 2.34 & 5.30 & 9.46 & 14.05 & 19.18 & 8 & 36.86 & 17.91 & 11.02 & 38.91 & 60.96 \\
\hline Deposits/GTA & 5050 & 82.11 & 12.20 & 74.78 & 80.74 & 84.88 & 87.69 & 89.49 & 8 & 81.45 & 5.32 & 73.80 & 81.05 & 88.41 \\
\hline
\end{tabular}

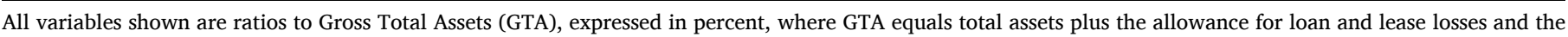

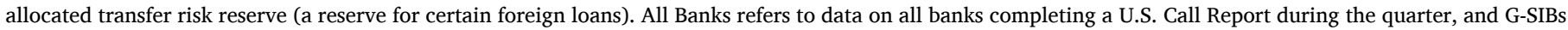

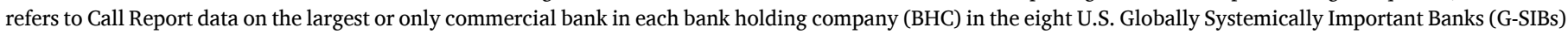

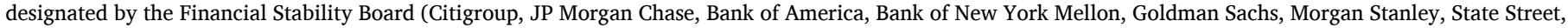
and Wells Fargo). 
various ratios to Gross Total Assets (GTA), expressed in percent terms. ${ }^{14}$ These ratios cover dimensions of bank condition (capital and liquidity ratios, based on equity and cash, due from, and securities, respectively), credit performance (charge-offs, nonperforming loans, loan and lease loss allowances), and portfolio allocations (loans, unused commitments, deposits) to see if the COVID-19 crisis caused significant distress in any of several areas of bank operations. For each ratio, we show for the entire U.S. banking industry the number of banks, mean, standard deviation (SD), and P10, P25, P50, P75, and P90 percentiles.

We also want to be sure that summary statistics for the industry are not masking any systemic risk being posed by large, systemically important institutions that could bring down the banking and financial systems. For this reason, we show additional summary statistics for the eight U.S. Globally Systemically Important Banks (G-SIBs). ${ }^{15}$ This relatively small number of banks are those deemed by international regulators to pose global systemic risks and hold more than half of all U.S. banking assets. For the G-SIBs, we show the number of banks, mean, SD, minimum (min), P50, and maximum (max), given that some of the other percentiles are not sensible for a sample of only 8 observations per quarter. $^{16}$

While there are many statistics that may tell complex stories in Table 1, in the interest of brevity, we narrow our focus in the text to the simplest cases. With only one exception of a potentially misleading mean, for all variables and all time periods and for both all banks and the G-SIBs subsample, we discuss only the mean and the extreme statistic $\mathrm{P} 10$, P90, min, or max - that would signal the worst performance problem if there were one. Thus, for the capital ratio, we focus on the mean and P10 for all banks, and the mean and the min for G-SIBs. In contrast, since high values are problematic for charge-offs, we look at $\mathrm{P} 90$ and max statistics instead of P10 and min, respectively.

\subsubsection{Bank conditions}

The bank equity ratio (equity/GTA) and similar ratios are frequently employed in banking research as summary measures for bank health and the ability to absorb shocks. As noted above, it is consistently measured over time and is not subject to temporary easing of what counts as regulatory capital during COVID-19. We find that the equity ratio is stable for the banking industry for the entire set of five quarters. The mean equity ratio for the U.S. banking industry stays in the tight range of less than one percentage point variation between $12.56 \%$ and $13.41 \%$, suggesting that the industry remained well capitalized throughout. Focusing next on the P10 points to see if there is trouble with the least capitalized set of banks, the figures range between $8.30 \%$ and $8.98 \%$, showing relatively little movement, no sign of a banking crisis, and much higher than in troubled times of the past.

We next turn to the bank liquidity ratio, which includes cash, due from, and securities normalized by GTA, for potential signs of trouble that might signal a liquidity problem that would require fire sales or reduced credit supply. The mean bank liquidity ratio varies from $30.33 \%$

\footnotetext{
14 GTA equals total assets plus the allowance for loan and lease losses and the allocated transfer risk reserve (a reserve for certain foreign loans). It is a more accurate representation of the size of the balance sheet than total assets because it includes all of the dollars of assets that need to be financed with bank equity and liabilities.

15 The Financial Stability Board (FSB) publishes a list of Globally Systemically Important Banks (G-SIBs) based on their scale and the degree of influence in global and domestic financial markets. In 2020, 30 institutions qualify, including eight U.S. institutions - Citigroup, JP Morgan Chase, Bank of America, Bank of New York Mellon, Goldman Sachs, Morgan Stanley, State Street, and Wells Fargo. The G-SIBs generally refer to bank holding companies (BHCs) that own commercial banks, rather than commercial banks themselves. The Call Report data in Table 1 is for the largest or only commercial bank in each BHC.

${ }^{16}$ We do not construct separate summary statistics for small banks, since the vast majority of U.S. banks have less than $\$ 1$ billion in assets. Thus, the summary statistics for the industry covers small banks well.
}

to $35.27 \%$, rising over time as banks become more liquid after the crisis starts. The P10 also rose from $12.69 \%$ to $17.34 \%$ over time as the industry becomes more liquid, clearly indicating that the COVID-19 crisis did not induce liquidity problems in the U.S. banking industry.

The U.S. G-SIBs, whose data are shown on the right side of the table, normally maintain significantly lower capital ratios and higher liquidity ratios than other banks. The mean capital ratio ranges between $9.13 \%$ and $10.54 \%$, with the minimum varying between $6.96 \%$ and $8.35 \%$. Again, these ratios achieved their minimums in 2020:Q1, and were recovering thereafter. As noted above, the Federal Reserve capped dividends and banned stock buybacks by large banks from June until the end of the year, which may have helped keep bank capital ratios from falling below healthy levels. Similar to the full sample, the mean liquidity ratio increased after the start of the COVID-19 crisis from $47.71 \%$ to $55.13 \%$ and the minimum rose from $28.03 \%$ to $39.14 \%$, indicating no liquidity problems.

\subsubsection{Bank credit performance}

We scrutinize several statistics to evaluate bank credit performance during the crisis. We examine credits that are recognized as current losses, represented by charge-offs; nonperforming loans with payment delays that may turn into credit losses, represented by the past due of at least 90 days plus nonaccrual ratio; and whether banks have enough funds set aside for expected losses, measured by loan and lease loss allowances. To the extent that current and impending losses are high and there are insufficient allowances for them, the industry could be in trouble. We again note that charge-offs and nonperforming loans could be biased downward for some institutions during the crisis due to forbearance rules on some bank debt.

Examining the credit performance data for the industry, mean charge-offs remain low throughout the time interval, and are actually lower after the COVID-19 crisis begins than their local peak of $0.14 \%$ in 2019:Q4. There is a minor upward movement in nonperforming loans from $0.61 \%$ in $2019: \mathrm{Q} 4$ to $0.65 \%$ in $2020: \mathrm{Q} 1$, but the ratio fell from there to $0.54 \%$ in $2020: \mathrm{Q} 4$. We acknowledge that these data means may obscure the view of some banks with more severe credit performance problems - researchers find that nonperforming loans problems are more concentrated where banks more exposed to the pandemic and lockdown policies (e.g., Beck and Keil, 2021). Switching to the more adverse values of these performance issues, however, does not raise alarm bells. The P90 for charge-off rates are lower in every quarter of 2020 than in 2019:Q4. The P90 for nonperforming loans is $1.42 \%$ in 2019:Q4, and is lower than that for every subsequent quarter except 2020:Q2, when it reaches $1.51 \%$, which is only slightly larger.

It is likely the case, as argued elsewhere (e.g., Beck and Keil, 2021), that reported loan performance would have been significantly worse were it not the case that the bank portfolios included hundreds of billions of dollars of Paycheck Protection Program (PPP) loans. These loans are largely not intended to be paid back, so should contribute little to nothing to charge-offs and nonperforming loans. As discussed in more detail below, this suggests that part of the "financial surprise" of a lack of banking crisis or significant financial distress is likely due to government stimulus during COVID-19 in addition to prior fortification of the industry in response to the GFC. Some of the improvements may also be illusory due to the forbearance rules discussed above, but it is not possible to determine how much this may be the case. Nonetheless, it is reassuring that reported loan performance problems did not significantly worsen during the crisis.

Checking next for insufficient loss allowances for the industry, this also does not appear to be problematic. The mean allowance of $0.81 \%$ in 2019:Q4 is slightly exceeded in every quarter of 2020, ranging between $0.82 \%$ and $0.84 \%$. Similarly, the P10 values of the allowance also modestly exceed the $0.36 \%$ in 2019:Q4 in 2020, ranging between $0.37 \%$ and $0.38 \%$. We cannot say whether the increase in allowances in 2020 are sufficient to cover the increased risks from the pandemic, but the banks at least made some effort to maintain slightly higher reserves to 
absorb these risks.

Turning to the credit performance data for the G-SIBs, the story is much the same - no substantial problems. Mean charge-offs are low in 2020 , between $0.05 \%$ and $0.14 \%$, and remain below the 2019:Q4 peak of $0.20 \%$. There is some upward movement in nonperforming loans, rising from $0.31 \%$ in the first two quarters to a peak of $0.43 \%$ in 2020 : Q4. However, in all cases, nonperforming loans for the G-SIBs are below the industry averages, suggesting no concentration of loan risk for the systemically important banks. For the most adverse values charge-offs, recoveries, and nonperforming loans, the maximum 2020 charge-off ratios are always below the 2019:Q4 maximum, and the maximum nonperforming loans for the large banks is in all cases below the P90 values for the industry.

We next check if loss allowances show any insufficiencies for the GSIBs. We find that the G-SIBs actually increased their allowances significantly. The mean ratio is $0.36 \%$ in $2019: \mathrm{Q} 4$, and ranges between $0.54 \%$ and $0.72 \%$ in the quarters of 2020 , suggesting the G-SIBs are prepared for credit losses. The minimum values of the allowance also increase in 2020, but are low throughout the sample period, between $0.03 \%$ and $0.05 \%$. This may reflect a risky G-SIB bank, but it is not an increase in risk during the COVID-19 crisis.

\subsubsection{Bank portfolio allocations}

We finally check bank portfolio allocations to investigate the possibility that there are some significant increases or decreases in major portfolio categories that may suggest banking industry problems. We specifically look at loans, unused commitments, and deposits.

The industry mean loan ratios declined significantly from $64.48 \%$ to $60.01 \%$ over the sample period, with a more modest decline for the P90 statistic from $82.45 \%$ to $79.15 \%$. A decline in loans generally suggests a reduction in credit risk, which would make the banks safer, although we caution that we do not know the risk characteristics of the loans that are retained. As discussed further in Section 6 below, the lending decline likely detracted from the "economic surprise" of the short recession, but it likely contributed to the "financial surprise" of a relatively healthy banking industry. It is not possible to discern the extent to which these declines may reflect changes in credit supply versus credit demand.

For the unused commitment ratio, we ignore the mean values, which may mainly reflect some extreme outliers, given that they are always many times greater than the P90 values. Focusing instead on the P50 and P90 values, they are both remarkably steady and suggest no significant increases or decreases. The P50 value remains in a tight range between $9.16 \%$ and $9.69 \%$ and the P90 statistic varies between $18.29 \%$ and $19.85 \%$.

The deposit ratios for the industry as a whole show only some very modest increases. The mean and $\mathrm{P} 90$ deposit ratios each increase less than one percentage point and stay near $81 \%$ and $89 \%$, respectively. However, as above for the loan ratios, the industry statistics may disguise some significant heterogeneity. One study using weekly branchlevel deposit data finds substantial movements of deposits and the rates paid on these deposits that vary with COVID-19 infection rates (Levine et al., forthcoming).

The loan ratios for the G-SIBs are much lower than for the industry, and again show substantial reductions in lending and possibly credit risk. The mean loan ratio declines from $36.80 \%$ to $31.49 \%$, and the maximum ratio similarly declines from $54.80 \%$ in 2019 :Q4 to $49.84 \%$ in 2020:Q4.

Unused commitments for the G-SIBs decline very considerably during the COVID-19 crisis, likely primarily due to the "dash for cash" by corporations drawing down their commitments at the largest banks described in some of the research discussed later in this paper. The P50 and P90 values fall from $48.48 \%$ and $69.29 \%$ in 2019:Q4 to ranges of $38.35-42.18 \%$ and $60.20-62.46 \%$, respectively.

Deposits at the G-SIBs increase more than for the industry as a whole, which may reflect in part a flight to safety by some depositors that believe these institutions are "too big to fail," as well as liquidity hoarding by corporate customers as part of the "dash for cash." The GSIB deposit ratios increase from mean and P90 values of $78.18 \%$ and $85.31 \%$ in $2019:$ Q 4 to $81.45 \%$ and $88.41 \%$ in 2020 :Q4, respectively.

\subsection{Additional statistics that do not depend on accounting data}

We evaluate whether bank failures during the crisis may have distorted the accounting data and masked significant problems in the U.S. banking industry. The FDIC reports only four of the over 5000 U.S. banks failed in 2020, including one failure on February 14 before COVID-19 slowed the U.S. economy. The failed banks had combined assets of just $\$ 458$ million in an industry with assets over $\$ 17$ trillion. ${ }^{17}$ These very mild failure data provide additional evidence that the banking system was not in significant distress, and also suggest that missing Call Reports from failing banks are not obscuring our view of any substantial industry problems.

We consider as well the possibility that accounting data may generally be less accurate indicators of bank financial distress than market indicators. The KBW Bank Index, which covers stock market values for 24 banking organizations, did fall from 113.4 to 97.9 from December 31, 2019 to December 31, 2020, and has since risen to 134.5 as of this writing on May 17, 2021. ${ }^{18}$ Thus, there were some market losses during the calendar year, but the index is currently higher than before COVID-19, not revealing any market value indications of forthcoming financial distress.

Another market-based measure is SRISK for the U.S. financial system, an indicator of systemic risk that is employed in many research studies. It rose from 286 to 562 from December 2019 to December 2020, but then fell to 247 in May 2021. ${ }^{19}$ Again, there was some market indication of risk during the year of 2020, but the financial system is measured as safer now than before the COVID-19 crisis.

Finally, some research suggests strong connections between public sentiment about banks and the general stock market in the U.S. John and Li (2021) find that an index of banking sentiment derived from Google search data reduces jump volatility in the S\&P 500 index during the COVID-19 pandemic.

\subsection{Suggestions for additional research on banks and financial markets in the remainder of the world}

We close this U.S.-oriented data section with suggestions for more research on banking and financial conditions in the rest of the world. We first note that while we remain unaware of visible banking crises outside of the U.S. during the COVID-19 crisis, we are less confident in the conditions of banks in other developed or developing countries. For most countries, there are fewer accessible comparable quality datasets, hindering similar investigations as in this paper. However, a key exception is Europe, which has a number of datasets available of equal or higher quality as the U.S. We recommend using these in future research.

Second, we have reasons to suspect that the favorable "surprises" observed in the U.S. may not be replicated in many other nations, which may be more likely to have unfavorable outcomes instead. Our reasons are that the causes of the U.S. "surprises" that we review in Sections 5 and 6 below likely do not hold to the same degrees elsewhere. While governments of many nations around the world also introduced stimulus programs, these were not as large or introduced as quickly as the U.S. did as discussed in Section 5 (e.g., Feyen et al., 2021). Additionally, the extent to which the safety of different banking systems were fortified and strongly capitalized following the GFC as in the U.S. as discussed in Section 6 varies significantly across the rest of the world (e.g., Anginer

\footnotetext{
17 https://www.fdic.gov/bank/historical/bank/bfb2020.html

18 https://www.nasdaq.com/market-activity/index/bkx/historical

19 https://vlab.stern.nyu.edu/welcome/srisk
} 
et al., 2021). We encourage future research on both the impact of the various stimulus programs and the post-GFC prudential reforms on banking systems performance during and after COVID-19 using international banking data.

Third, the problems noted above for the U.S. with the potential to create near-term economic and banking problems - such as economic dislocations, inflation, and financial market issues created by the crisis and policy responses - are likely to be even more threatening of nearterm problems in other countries. For example, some countries relaxed their banking regulations on nonperforming loan provisioning and classification much more than in the U.S. (e.g., Feyen et al., 2021). Moreover, borrower assistance and prudential measures may have exacerbated the bank stress significantly in countries that operate with little fiscal space due to strongly expansionary fiscal and monetary policies (e.g., Demirgüç-Kunt et al., 2021b; Reinhart, 2021). When these forbearance policies come to an end and fiscal and monetary support are reduced, the extent of financial sector problems will become clearer. If the crisis has indeed seriously damaged financial institutions' balance sheets, repairing such damage will take time, possibly leading to deleveraging and credit crunches that can hamper recovery in these countries for many years. We suggest that both policy makers and researchers pay close attention to these issues around the world.

We strongly encourage more international banking research for the same reason brought up in the introduction for why crises are so informative to research. The best way to learn what works is to study what happens when things do not work. It is likely that future research will uncover a significant number of things not working across the world during COVID-19.

We call researchers' attention to the fact that COVID-19 also did not result in any long-lived crises in financial markets, although these markets are not the main focus of this article. U.S. stock markets fell sharply initially, and demonstrated a strong negative reaction in the skewness and total market price of risk, more negative even than the GFC (Delis et al., 2021). The contagion effects across stock markets in different nations was also quite pronounced during COVID-19 (e.g., Iwanicz-Drozdowska et al., 2021). However, the market came back even stronger during the pandemic, likely due in part to the policy interventions that helped the real economy and Federal Reserve policies that boosted financial markets. The S\&P 500 index achieved a record closing high of 3386 on February 19, 2020. However, 16 sessions later, the market closed at 2481 on March 12, 2020, a decline of about $26 \%$, a bear market. Nonetheless, financial markets have now recovered, with the S\&P 500 closing at 4,163 on May 17, 2021. However, Demirguc-Kunt et al. (2021b) analyze stock price data to show that banks around the world, particularly those that operate in countries with little fiscal space, were put under stress in 2020 despite many policies introduced to moderate this impact. ${ }^{20}$ We recommend that future research extend this analysis to monitor these vulnerabilities and developments across the world.

\section{Key reason for the "economic surprise" - government stimulus programs during COVID-19}

We argue in this section that a key reason why the COVID-19 economic outcomes in the U.S. became a favorable "surprise" may be the large government stimulus programs that were quickly put into place

\footnotetext{
20 Ding et al. (2021) explore the determinants of stock price reactions to the pandemic for nonfinancial corporations around the world.
}

during the crisis. Both the COVID-19 and GFC crises featured many stimulus programs in the U.S. from government payments to households, to aggressive Federal Reserve interest rate targeting and asset purchases, to large bailouts of firms and markets, but these actions were much faster and larger during COVID-19. ${ }^{21}$

To illustrate, the GFC had started in the U.S. by August 2007 and the recession had begun by December 2007, but the main policy responses were not until late 2008 or 2009 . While some Federal Reserve actions were reasonably fast, ${ }^{22}$ the fiscal stimulus did not occur until 2009 and was under $\$ 1$ trillion, the Federal Reserve did not change its target range for the federal funds rate to the lower bound of $0-25$ basis points and begin its large asset purchase programs until late 2008, and the Treasury's TARP bank bailout did not start until October 2008.

In contrast, the COVID-19 crisis and recession started in late February 2020, and the larger policy responses were underway the very next month. In March, the much larger fiscal stimulus in the multiple trillions of dollars, the Federal Reserve near-zero federal funds rate targeting and purchases, and the PPP bailout that was several times larger than TARP were enacted, and the PPP funds were flowing by April.

Despite the much slower start and smaller magnitudes of some of the policy moves in the GFC relative to the COVID-19 crisis, it is notable that one study finds that Federal Reserve emergency policies during the GFC may have been more effective in containing systemic risk than those during COVID-19. Sedunov (2021) finds that lender of last resort and liquidity provision during the GFC were effective in reducing systemic risk in the U.S. and in some cases other nations as well. However, the author finds no relation between Federal Reserve actions and systemic risk during the first part of the COVID-19 crisis. An international study of systemic risk during the COVID-19 crisis suggests other moderating effects. Duan et al. (2021) finds that the increased systemic risk caused by the crisis is moderated by bank regulation, such as deposit insurance; ownership structure, such as foreign and government ownership, and informal institutions, such as culture and trust.

In the interest of brevity, we contrast one large comparable policy program from each crisis - the TARP bailout of banks during the GFC and the PPP bailout of small businesses during COVID-19. ${ }^{23}$ Both bailouts were targeted toward where the largest problems were - bank distress in the GFC and the distress of small businesses and their employees during COVID-19. However, key differences are that the PPP was a much larger and more widely applied stimulus and occurred much earlier in its crisis than TARP.

\subsection{TARP}

The TARP bank bailout passed Congress on its second try in October 2008 as part of Emergency Economic Stabilization Act of 2008 (EESA). Its main goals were to save the real economy and financial system via purchasing up to $\$ 700$ billion of "troubled assets" for which markets

\footnotetext{
21 The timing and strictness of lockdowns and other restrictions introduced at the state-level may have also contributed to the speed of recovery across states (e.g., Demirgüç-Kunt et al., 2021a). In the interest of brevity, we only focus on aggregate recovery and the fiscal stimulus, but how the restrictions interact with the speed and size of the stimulus may be an interesting area of future research.

22 On August 17, 2007, the Federal Reserve began offering discount window funds with maturities beyond overnight, and it created the Term Auction Facility (TAF) on December 12, 2007 to future encourage bank borrowing from the Federal Reserve. Research is mixed on the benefits of these programs (e.g., Cyree et al., 2013; Armantier et al., 2015; Berger et al., 2017; Helwege et al., 2017). The Federal Reserve Open Market Committee also started decreasing its federal funds target on September 18, 2017, lowering it by 50 basis points to $4.75 \%$.

${ }^{23}$ Details of initial policy responses to COVID-19 in the U.S. and around the world may be found in International Monetary Fund (2020).
} 
were frozen or asset values were massively depressed. This would allow markets to stabilize, avoid further losses, and encourage banks to increase lending to improve the real economy.

TARP was later changed to a direct bailout of banks. Its main component, the Capital Purchase Program (CPP), invested in the preferred equity of selected financial institutions to enhance their capital ratios. This included an initial total of $\$ 125$ billion to nine large institutions (Citigroup, Bank of America, J.P. Morgan Chase, Wells Fargo, Goldman Sachs Group, Morgan Stanley, State Street Corporation, Bank of New York, and Merrill Lynch) on October 28, 2008. These nine institutions were essentially involuntary participants, who were strongly encouraged to take the funds, possibly to reduce any stigma associated with the program and/or disguise which large banking organizations may have been in most financial distress. TARP eventually infused $\$ 204.9$ billion into 709 banking organizations including the $\$ 125$ billion to the first 9 institutions. It was initially expected that the U.S. Treasury would lose money, but eventually it recovered $112.7 \%$ of the total money invested. ${ }^{24}$ On an expost facto basis, this was a relatively low rate of return to U.S. taxpayers, given the risks (e.g., Flanagan and Purnanandam, 2021). ${ }^{25}$

Our review of the TARP research that follows is limited to discussion of how well the program achieved its primary goals of promoting the real economy and reducing risks. For more complete reviews of TARP research, see Calomiris and Khan (2015), Berger (2018), Roman (2019), and Berger and Roman (2020).

There is significant evidence that TARP improved the real economy in the U.S., which may have shortened the recession. One direct study of the effects of TARP on the real economy finds significant improvements in multiple economic conditions affecting households and businesses at the state level (Berger and Roman, 2017). Others find that TARP softened the unfavorable real economic impacts of bank failures that did occur (e.g., Contreras et al., 2021a, 2021b).

A key channel though which TARP may have improved the real economy is increased bank credit supplies, and there are many investigations of these credit supply effects. Most such studies find positive effects, but there are key differences in results by bank and borrower size. Some studies of credit supply by large banks to large businesses find increases in credit supply (e.g., Berger et al., 2019), and these large businesses also used some of the funds to significantly increase their trade credit to their partners in the supply chain (e.g., Norden et al., 2020). Others find no changes in credit supply by large banks (e.g., Duchin and Sosyura, 2014).

To the extent that TARP was successful in increasing credit supply to large businesses, the market values of the large relationship borrowers would likely increase. Studies of this issue are also mixed, with both increases and decreases in relationship firm value reported (e.g., Norden et al., 2013; Lin et al., 2017).

However, the studies that focus on either small business loans or include small banks that mostly make small business loans generally find positive credit supply effects of the program (e.g., Taliaferro, 2009; Black and Hazelwood, 2013; Li, 2013; Puddu and Waelchli, 2015; Jang, 2017). This support for more credit to small businesses may be critical for the real economy because small businesses are generally much more often financially constrained than large businesses.

We next turn to the issue of the banking crisis. The GFC banking crisis was in effect for more than a year and worsening by the time that TARP began, so the relevant issue is whether TARP helped reverse the banking crisis by reducing systemic risk. One study addresses the question

\footnotetext{
${ }^{24}$ http://www.treasury.gov/initiatives/financial-stability/reports/Pages/ Monthly-Report-to-Congress.aspx

${ }^{25}$ However, other research using conference call transcripts suggests that bank managers thought that the funds were relatively expensive ex ante after the Federal Reserve had lowered the federal funds target to near zero (Helwege and Liu, 2021).
}

directly by measuring whether TARP banks increased or decreased their contributions to systemic risk. Berger et al. (2020b) use systemic risk measures and find evidence that TARP decreased systemic risk contributions. The finding is mostly due to a reduction in market leverage risk by TARP banks. Consistent with this, several studies also find that TARP reduced accounting-based leverage risk by increasing common equity-to-assets ratios of recipients (e.g., Duchin and Sosyura, 2014; Calabrese et al., 2017; Berger et al., 2020b). One study suggests that some troubled TARP banks may have raised capital and kept up their dividend payments due to threats of Treasury Department appointments of outside directors under a provision of TARP (Muecke et al., 2021).

However, somewhat offsetting the decreased leverage risk appears to be increased portfolio risk from several sources. The increase in credit supply to small businesses discussed above clearly increased portfolio credit risk. There are also studies finding that large banks shifted into riskier credits or eased credit terms more for riskier borrowers (e.g., Duchin and Sosyura, 2014; Black and Hazelwood, 2013; Berger and Roman, 2017; Berger et al., 2019; Cao-Alvira and Nuñez-Torres, 2019).

A few studies examine overall risk at the bank level, as opposed to the system level, using measures such as Z-score. These authors mostly find increased bank risk (e.g., Duchin and Sosyura, 2014; Del Viva et al., 2017; Semaan and Drake, 2016), although one study finds reduced overall bank risk (Berger et al., 2020b).

Despite the short-term benefits of TARP in terms of reducing systemic risk during the heart of the GFC and improving the real economy during the Great Recession, there were also some long-term costs, of which we briefly just mention two. The research suggests that moral hazard incentives were created, with some TARP banks shifting into riskier loans (e.g., Duchin and Sosyura, 2014; Berger et al., 2019), mixed results on market discipline (e.g., Forssbæck and Nielsen, 2016; Berger et al., 2021e), and higher estimated systemic risk in the long run (Berger et al., 2020b). TARP funds may have also kept alive some banks that should not have stayed in business, given the evidence that political connections were involved in some banks obtaining the funds (e.g., Duchin and Sosyura, 2012, 2014; Blau et al., 2013; Li, 2013; Berger and Roman, 2015, 2017; Berger et al., 2019, 2020b; Chavaz and Rose, 2019).

\section{2. $P P P$}

The PPP bailout of small businesses during the COVID-19 crisis was part of the 2020 CARES Act that was passed into law on March 27, 2020, only about a month into the crisis and recession. In addition to being much faster than TARP, the PPP was an even bigger bailout of small businesses than TARP was of banks. The $\$ 525$ billion dollars distributed to 5.2 million small businesses during the first round of PPP was much larger than the $\$ 204.9$ billion of TARP funds for 709 banking organizations, and most of the PPP funds did not have to be repaid with interest to the government, contrary to the TARP conditions.

The PPP was reopened with additional funds on January 11, 2021, well after the recession ended. ${ }^{26}$ The research discussed here focuses on the first round of PPP both because only the first round could have helped end the recession and promote the "economic surprise" and because there has been insufficient time for researchers to analyze the second round. We encourage future research on the second round and the extent to which it may helped continue economic growth and other effects.

The PPP was aimed at providing economic relief to small businesses affected by COVID-19 and incentivizing these businesses to keep their workers on payroll and reduce the incidence of unemployment. The

\footnotetext{
26 The program was closed to new applications by the SBA on May 28, 2021 "due to the high volume of originations...," although more of the total of $\$ 961$ billion total available for the PPP program were to be processed after that date. As of May 23, 2021, about $\$ 796$ billion in loans were approved over the first and second rounds (Omeokwe, 2021).
} 
Small Business Administration (SBA), which administers the program, forgives loans if all employee retention criteria are met, and if the funds are used for eligible expenses, including payroll, so many low-income households were likely aided as well. The loan forgiveness rules - that the loans are forgiven if the funds are used as intended for 8 weeks suggest that the PPP is presumably designed to be short-term in nature. As discussed below in Section 7, the PPP almost surely aided the banks as well and helped contribute to the "financial surprise" of their remarkable resilience during the COVID-19 crisis.

In contrast to the limits we placed on our review of the TARP research, we review to the extent possible all of the empirical research on PPP to date, recognizing that we are likely missing a number of contemporaneous working papers that are coming out at this time. The empirical PPP research literature does address a surprisingly large number of important questions, given how recently the program was initiated. However, as will become clear, there is too little attention to date on most of these issues, requiring additional future research.

Some research investigates the extent to which PPP recipient firms, their employees, and communities benefited from the program. Starting with the PPP firms, one paper finds that the PPP helped alleviate the financial and economic constraints of relatively small recipients - those with nine or fewer employees - leaving the owners of these firms more satisfied with their access to credit and better able to hire and pay their employees (Berger et al., 2021b). ${ }^{27}$ These authors also find that these results hold only in the short-term, a month or two at most, consistent with the presumed short-term design of the program. Other research suggests that PPP had mixed results on firm credit scores, and helped only modestly with medium-term survival (Hubbard and Strain, 2020), which another study finds improvements in medium-run firm survival, but only for microbusinesses (Bartlett and Morse, forthcoming).

Those that investigate employment effects at PPP recipient firms have positive outcomes of different degrees. Some papers suggests that PPP loans increased employment at small businesses only modestly (e.g., Chetty et al., 2020; Hubbard and Strain, 2020), another concludes that PPP may have boosted employment on the order of about $3.5 \%$ at eligible firms (Autor et al., 2020), and a third suggests that PPP firms were nine percentage points less likely to reduce employment (Humphries et al., 2020).

Turning to the community level, a number of studies link PPP with reduced unemployment (Barrazza et al., 2020; Bartik et al., 2020; Granja et al., 2020; Duchin and Hackney, forthcoming; Li and Strahan, forthcoming). One study also suggests that subprime consumer debt declined in local markets in which banks made more PPP loans (Berger et al., 2021a). ${ }^{28}$

A key issue is whether PPP funds serve as substitutes versus complements for conventional loans from banks and other financial institutions. In theory, the PPP funds might have essentially substituted for credit from banks and other financial institutions, in which case other loans from these institutions would decline as a result of the program, with relatively little net total increase in small business funding. Alternatively, PPP funds may have made the recipient firms more creditworthy, and allowed them to borrow more conventional credit, resulting in a "multiplier effect" (Karakaplan, 2021). In addition, any subsidies to the banks from the fee income and rescues of their relationship borrowers may allow the banks to supply more credit to other borrowers. Distinguishing between these different potential outcomes is important for determining the extent to which the PPP program actually increased access to funds for small businesses and by how much.

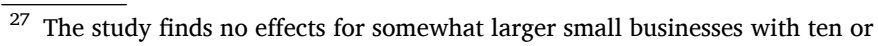
more employees, but it does not cover relatively large firms close to the 500employee limit for the program.

${ }_{28}$ This same study finds opposing results for localities with more TARP banks during the GFC. Subprime consumer debt increased where more banks were bailed out.
}

Four studies using bank Call Report data find very strong multiplier effects supporting complementarities. Karakaplan (2021) finds that conventional small business loans of up to $\$ 1$ million went up on the order of magnitude of an additional dollar of conventional loans for a marginal dollar of PPP loans, particularly for small banks. Berger et al. (2021d) similarly find strong positive effects especially for smaller banks and smaller businesses. Marsh and Sharma (2021) also find significant increases in lending by small banks, while Lopez and Spiegel (2021) find increases in small business and farm lending by all bank sizes. In contrast, another study using the Federal Reserve's Y-14 data on conventional loans over $\$ 1$ million suggests strong substitution effects. Chodorow-Reich et al. (forthcoming) find firms that receive PPP loans obtain fewer conventional credits over $\$ 1$ million from very large banks. Thus, there may be key differences by firm and bank size that need more research to obtain a clearer picture of the answer to this important question. $^{29}$

Some research focuses on the financial institutions that issued the PPP loans. Several studies find that small, community banks played an outsized role in PPP, disbursing outsized shares of the PPP loans (e.g., Levine et al., 2020; James et al., 2021). Another study finds that FinTech firms also played a key role in distributing PPP funds, providing greater roles in local markets with fewer bank branches, lower incomes, larger minority shares of the population, in industries with bank small business lending (Erel and Liebersohn, 2020).

There may also be some long-term costs of PPP to the extent that the funds were misused or were allocated to unproductive firms that should otherwise not be kept alive. One theoretical study emphasizes the potential for misallocation of the PPP funds to firms by banks (Joaquim and Netto, 2021). Some empirical evidence suggests that some PPP funds were not employed as intended, despite rules on uses of funds (e.g., Granja et al., 2020). Larger firms may have received outsized amounts, despite program limits. One study finds that fraud was much more prevalent in the distribution of PPP funds by FinTech firms (Griffin et al., 2021). The Small Business Administration (SBA) reports that $1.6 \%$ of the initial 5.2 million loans received $\$ 1$ million or more each, accounting for about $34 \%$ of the funds. ${ }^{30}$ About 600 firms obtained the maximum loan amount of $\$ 10$ million. ${ }^{31}$ One study suggests that information frictions and the "first-come, first-served" design of the program favored larger firms (Humphries et al., 2020). Another paper also finds that larger borrowers enjoyed earlier access, particularly from large banks, and documents significant hesitancy to take the PPP funds or return the funds by many firms as well (Balyuk et al., 2021). There is also some evidence of fewer funds for minorities, with one study finding that Black-owned firms received about half the amounts of observationally similar white-owned businesses (Atkins et al., forthcoming).

Some researchers also find evidence consistent with the policy suggestion of prioritizing firms with existing bank relationships (e.g., Amiram and Rabetti, 2020; Bartik et al., 2020; Balyuk et al., 2021; Li and Strahan, forthcoming). One of these studies suggests that while large firms are often prioritized, this effect is mitigated for small firms with relationships with small banks, likely reflecting the importance of small firms to small banks (Balyuk et al., 2021). The priorities given to relationship borrowers could be either an efficient use of funds to known borrowers with histories of repayment, but could also reinforce existing inequities in the distribution of conventional bank loans.

Additional research suggests that PPP funds may have been allocated to some extent according to political connections. Duchin and Hackney

\footnotetext{
${ }^{29}$ Although it is not our focus here, some evidence suggests that another much smaller program to stimulate bank lending, the Main Street Lending Program, also increased bank lending outside the program (Minoiu et al., 2021).

${ }^{30}$ https://home.treasury.gov/system/files/136/SBA-Paycheck-ProtectionProgram-Loan-Report-Round2.pdf

31 https://www.nytimes.com/2020/12/02/business/paycheck-protectionprogram-coronavirus.html
} 
(forthcoming) find that partisan politics played a role. PPP funds were more likely to fund small businesses in battleground states and congressional districts where Democratic and Republican voters are relatively equally split and to Republican areas. Their findings suggest that PPP funds may have directed to small businesses in part to sway the 2020 presidential and congressional elections toward Republicans. ${ }^{32}$

Berger et al. (2021d) find that the partisan political connections of the banks that provided the PPP funds influenced the distribution of these funds, but those of the small businesses did not. The setup of the PPP approval process facilitated this. The small businesses applied to the banks (and other financial institutions), and the banks chose among the small businesses and presented the cases to the Small Business Administration (SBA) for approval, so that the SBA effectively picked the banks as much if not more than the small businesses. The fee structure and other benefits to the banks from PPP discussed in Section 7.2 below may have also motivated the banks to use their political connections. These authors also find that nonpartisan political connections matter for the small businesses - they were more likely to obtain PPP funds if their local U.S. Congressional Representative was a member of the House Small Business Committee, independent of party. The representatives may have acted to provide constituent services to the small businesses in their districts to help reassure their own reelections. Thus, the political connections of both the banks and the small businesses may have helped influence the distribution of PPP funds - partisan political connections for the banks and nonpartisan connections for small businesses.

\section{Key reason for the "financial surprise" - bank prudential policy responses to the GFC}

We next argue that bank prudential policies put into place in the U.S. in response to the GFC likely made the banking system more resilient to future crises and helped create the favorable U.S. "financial surprise." The safer, better capitalized, and more prepared banks of 2020 likely directly reduced the probability of a banking crisis and improved bank performance during COVID-19.

Bank prudential regulation and supervision are designed in large part to reduce the likelihood and severity of future bank financial distress in the event of a crisis or other adverse scenario. To the extent that regulators and supervisors are successful in these goals, the likelihood and severity of future banking crises may also be reduced. The primary tools used in these endeavors - such as capital and liquidity requirements, stress tests, activity restrictions, and prudential supervision - may be called "first lines of defense" that mitigate bank risks before financial distress occurs through different mechanisms (Berger and Roman, 2020).

A second key component of bank prudential regulation and supervision is the set of resolution policies that are employed when banks become financially distressed and are in danger of failure. These policies include bailouts, bail-ins, reorganizations using living wills, forbearance, and allowing the banking organizations to fail. While the main purpose of resolution policies is to find the best ex post facto outcome of the financial distress for society, these policies also provide ex ante risktaking incentives for the banks. The most well-known of these is the moral hazard incentive to undertake excessive risk from bailouts.

Both the first lines and the resolution policies were substantially toughened in the U.S. in reaction to the GFC to make the banks safer and better fortified against future crises and other adverse scenarios. Among the "first lines" changes were higher capital requirements, formal liquidity requirements for the first time, annual stress tests for the first time, more activity restrictions, and increased supervisory scrutiny. Resolution policy changes included introduction of a bail-in regime and living will requirements.

\footnotetext{
32 These authors also find that the political orientations of the small businesses' industries may have affected the allocation of PPP funding.
}

In the interest of brevity, we cover only "two and a half" of the lines of defense - higher capital requirements, introduction of stress tests, and increased microprudential supervisory scrutiny that were strengthened or introduced during and after the GFC. We exclude macroprudential scrutiny, the other "half" of the prudential scrutiny line of defense, as explained below. We also discuss one resolution policy change - the adoption of the Orderly Liquidation Authority (OLA), a type of bail-in regime. We briefly describe each of these changes and review extant research on their effects on bank risk.

We again note that the purpose of this paper is to not to provide rigorous econometric analysis of the "surprises" and their causes, but rather to be suggestive and leave the econometric analysis to future researchers. We show statistics above in Table 1 Panel A that reflecting a fortified U.S. banking sector going into the crisis in 2019:Q4 with strong capital and liquidity bank conditions, little in the way of credit performance, and reasonable portfolio allocations. We argue that this fortification is partly due to the strengthening/introductions of "first lines" and resolutions policies that we describe here and for which we provide extant research background.

\subsection{Higher capital requirements}

Capital requirements generally specify regulatory minimum accounting capital ratios. Numerators include equity and low-priority financial instruments that absorb risks, and denominators consist of assets and off-balance sheet activities that are sometimes weighted to reflect their perceived effects on portfolio risks. Banks often must comply with multiple ratios to reduce the likelihood of regulatory arbitrage or "gaming" the requirements. Higher requirements are also sometimes imposed on large, complex institutions that individually pose risks to the financial system for the purpose of counteracting systemic risk.

After the GFC, banks in the U.S. and many other nations were transitioned into Basel III capital requirements, which require compliance with four capital ratios. The requirements are significantly tougher and include an additional capital ratio relative to the Basel I requirements that most U.S. banks were previously following. The new requirements are also much more rigorous than the Basel II requirements into which some of the large banks were transitioning. The G-SIBs are also required to hold additional capital buffers because of their contributions to systemic risk. See Van Der Weide and Zhang (2019) for a more complete details on capital requirements generally and Basel III in particular.

Before turning to the research on capital requirements and bank risk, we first distinguish between actual bank capital ratios and capital requirements, since most of the relevant research employs actual ratios, rather than changes in requirements. Actual ratios are determined by a mix of regulatory requirements, supervisory pressures on individual banks to hold higher capital ratios, and "market capital requirements" on each institution. "Market capital requirements" are the capital ratios that individual banks would hold in the absence of regulation and supervision. These "requirements" reflect trade-offs among the effects of taxes, costs of financial distress, transactions costs, asymmetric information, and other deviations from the frictionless world assumptions of Modigliani and Miller's (1958) that would otherwise make capital ratios irrelevant to markets (e.g., Berger, 1995; Berger et al., 1995; Thakor, 2019).

Most U.S. banking organizations, including the largest, hold capital ratios well in excess of what is required by regulators and supervisors, and these banks adjust these ratios often in response to market forces (e. g., Berger et al., 2008). These findings suggest that "market capital requirements" are important, so care must be taken not to confuse the research findings on the effects of a given increase in actual capital ratios with the effects of the same magnitude increase in capital requirements.

In theory, capital requirements reduce leverage risks because if equity capital is higher as a result of these requirements, it serves as a cushion to absorb losses, reducing leverage risks. To the extent that the 
requirements result in higher actual capital ratios, these requirements may also reduce moral hazard incentives to take on excessive portfolio risks are engendered by limited liability, deposit insurance, and other government protections, such as "too big to fail." Moral hazard incentives to take on risks are blunted by forcing shareholders to bear more of the losses from these risks (e.g., Admati et al., 2013; Anginer and Demirgüç-Kunt, 2019; Thakor, 2019). Risk-based capital requirements may additionally reduce portfolio risks by encouraging safer choices that reduce the capital ratio denominators. To the extent that capital requirements successfully operate through this prudential mechanism of encouraging banks to reduce their risks, there may also be a certification mechanism in which the nonbank public is better assured of bank safety, reducing the incidence of destructive runs by risk-sensitive counterparties.

It is alternatively argued by some that banks may react to higher capital standards by taking on other portfolio risks to counteract reduced leverage risk and increase rates of return for shareholders (e.g., Koehn and Santomero, 1980; Kim and Santomero, 1988; Calem and Rob, 1999). This could also increase the incidence of destructive runs. See Freixas and Rochet (2008) for a review of the theories that suggests that the reduced-risk view generally dominates.

The empirical literature overwhelming suggests that higher capital ratios are associated with lower bank risk. Almost all U.S. bank failure studies find that higher capital reduces the likelihood of failure (e.g., Cole and Gunther, 1995; Wheelock and Wilson, 2000; Cole and White, 2012; DeYoung and Torna, 2013; Berger et al., 2016). Anecdotal evidence from U.S. history with also suggests that higher capital requirements themselves are also associated with reduced incidence of bank failures. There were many U.S. bank failures per year during the problem years of the late 1980s and early 1990s - sometimes exceeding 200 per year - before full implementation of Basel I capital requirements and leverage requirements imposed under the FDIC Improvement Act of 1991. There were far fewer during and after the GFC in which these requirements were in force, and as noted above, only four very small $\mathrm{U}$. S. banks out of over 5000 failed during 2020.

Also important for drawing conclusions about the effects of increased capital requirements imposed prior to the COVID-19 crisis are studies of the effects of bank capital ratios during prior crises. Studies find that during both U.S. banking and market crises of the past, banks with higher capital ratios fared much better than other banks during these crises. ${ }^{33}$ More capitalized banks had reduced likelihoods of failure and other financial distress resolutions, decreased risk, higher profitability, and increased market shares during these crises (e.g., Berger and Bouwman, 2013; Assaf et al., 2019).

Thus, the theoretical and empirical research literatures support the notion that increased capital ratios from the U.S. implementation of Basel III capital requirements likely helped reduce bank risk and helped produce the U.S. banking "surprise." This is subject to the limitations noted about drawing conclusions for capital requirements mostly from research on actual capital ratios. One study of the condition of the banking industry during the COVID-19 pandemic credits capital and liquidity requirements for making the industry resilient (Abboud et al., 2021).

Notably, Basel III also includes countercyclical capital buffers, additional capital that can be built up during booms, and drawn down during problem periods. Many nations, including 12 in Europe, have such buffers, but the U.S. implementation of Basel III does not require any buffer. ${ }^{34}$ It is argued that such a buffer could have resulted in even better U.S. bank performance during COVID-19 (Kohn, 2020). There is

\footnotetext{
33 Berger and Bouwman (2013) describe banking and market crises as those that originated in the banking sector and that originated outside banking in the financial markets, respectively, and identify two banking crises and three market crises between 1984 and 2009.

34 https://www.esrb.europa.eu/national_policy/ccb/html/index.en.html
}

also evidence that relaxation of the supplementary leverage ratio (SLR) in April 2020 was instrumental in promoting bank credit provision, contributing to the "financial surprise" (Koont and Walz, 2021). We encourage more research on the effects of changes in capital requirements around the world on bank risk and financial crises, including the effects of countercyclical capital buffers.

\subsection{Introduction of stress tests}

Stress tests evaluate whether banks have sufficient capital to continue lending and engaging in other banking functions in simulated adverse future scenarios. Institutions that fail the tests are generally required to take actions to shore up their capital through restricting dividends and share buybacks, and in some cases actively issuing new capital. Stress tests are essentially forward-looking capital requirements that mandate sufficient capital to absorb future risks. The forwardlooking nature differs from the backward-looking risk perceptions used in the risk weights in conventional capital requirements, such as Basel III. Key issues in stress testing include the disclosure of supervisory private information (e.g., Goldstein and Sapra, 2014), the reputation of the supervisor (e.g., Shapiro and Skeie, 2015), and the choices of the adverse scenarios (e.g., Parlatore and Philippon, 2021).

Bank stress tests began in the U.S. and Europe during the GFC, and there have been three U.S. programs since then. The Supervisory Capital Assessment Program (SCAP) was a one-time test in 2009 that was intended in part to help assure the public of the safety of the largest 19 banks with over $\$ 100$ billion in assets. The Comprehensive Capital Analysis and Review (CCAR) and the Dodd-Frank Act Stress Tests (DFAST) are annual events that started in 2011 and 2013, respectively, and remain on-going for large U.S. banking organizations, although the exact bank size cutoffs for inclusion vary over time. Details on U.S. stress tests may be found in Berger and Roman (2020), Chapter 22).

Theoretically, stress tests work similarly to conventional capital requirements and may reduce bank risks through both the prudential and certification mechanisms, but could be counterproductive if banks react by increasing risks. Theoretically, at least, stress tests may be more effective than conventional capital requirements in preparing banks for crises such as COVID-19 because of their forward-looking nature.

The extant empirical evidence on the effects of U.S. stress tests is mostly on performance during normal times and suggests that stress tests reduce bank risk. Research finds that stress-tested banks increased interest rate spreads on commercial loans, particularly to relatively risky DealScan borrowers, and cut back their small business loans, all of which reduce credit risk, and also register higher capital ratios, reflecting less leverage risk (Acharya et al., 2018). These banks are also found to cut back credit supply to small businesses (Covas, 2017; Cortés et al., 2020), reduce loan quantities to DealScan borrowers (Connolly, 2018; Berrospide and Edge, 2019), and reduce credit limits to credit card customers (Agarwal et al., 2021), further evidence of reduced credit risks.

There are fewer research papers on stress tests than on conventional capital requirements due to the relative newness of stress tests and their applications only to large banks. Nonetheless, the findings are consistent with those for conventional requirements, and suggests that another of the prudential policies put into place in the U.S. in response to the GFC likely contributed to a safe banking system and a "financial surprise" during COVID-19.

\subsection{Increased microprudential supervisory scrutiny}

We distinguish between microprudential supervision, which focuses on the safety and soundness of individual banks, and macroprudential supervision concerning overall financial stability. As noted, we limit attention to increased microprudential supervision "half" here for brevity.

Microprudential supervisors engage in three main activities to limit the risks of individual banks. They assess compliance with bank 
prudential rules and regulations, monitor for excessive individual bank risks through off-site and on-site examinations, and take formal or informal actions against banks that are out of regulatory compliance or excessively risky.

Evaluation of whether this supervision became stricter during and after the GFC, and research on whether such changes likely made banks safer going into the COVID-19 crisis are difficult because information on the key elements of monitoring, on-site examinations, and informal actions are all confidential. For example, much of what prudential supervisors do is conduct on-site examinations, evaluate whether the banks are excessively risky, and pressure the banks to hold higher capital ratios to offset these risks, but none of these are public information.

Much of what is known is from research by economists at regulatory agencies that have access to confidential information. Other research that is not limited to regulatory agency personnel employs observations on formal supervisory enforcement actions (EAs) taken against individual banking organizations or managers that are publicly reported by the supervisory agencies. EAs include cease and desist orders that stop illegal or unsafe practices, formal agreement consent orders that banks agree to that correct past deficiencies or violations, and sanctions against individual managers, such as removing them from the bank (see Berger et al., forthcoming, for more details). Finally, we may infer some of the effects on microprudential supervision on risk from the research summarized above on the effects of bank capital, since much of what supervisors do is encourage or require more bank capital. Thus, the earlier-reported finding that higher capital ratios are associated with lower bank risk provide some prima facie evidence that microprudential supervision also reduces bank risk.

Both anecdotal and research evidence suggests that U.S. supervisors stepped up their regulatory scrutiny during and after the GFC. Many articles in the popular press reported incidents of representatives of supervisory agencies engaging in formal and informal meetings with the board members of banking organizations to discourage risk-taking. EAs also increased dramatically, more than doubling from a total of 2129 in the three years from 2006 to 2008 , to 4605 in the three years from 2009 to 2011 (Srinivas et al., 2015).

Theoretically, microprudential supervision may reduce risks by incentivizing or forcing banks to correct their deficiencies or hold more capital to protect against themselves from other risks, and by reducing the likelihood of destructive panic runs by market participants that believe that the banks are safe (e.g., Barth et al., 2006). Alternatively, supervision could be counterproductive if it is politically abused, corrupt, or inefficient in evaluating risks, if it results in excessively lax market discipline of banks, or if the revelation of supervisory actions such as EAs causes panic runs (e.g., Shleifer and Vishny, 1988; Quintyn and Taylor, 2003).

The empirical evidence is generally consistent with reduced bank risks from supervision. A number of papers suggest that bank examination results provide valuable information about risk beyond what is available from accounting data (e.g., DeYoung et al., 2001; Gunther and Moore, 2003; Wheelock and Wilson, 2005) and also have information beyond market data (e.g., Cole and Gunther, 1998; Berger et al., 2000). Of course, more important to whether this supervisory discipline works to reduce risks is how this valuable information is employed. One paper focuses on EAs against publicly traded banking organizations and finds that EAs result in reduced individual bank risk and systemic risk (Berger et al., forthcoming). The risk reductions operate through several channels of reduced leverage risks and portfolio risks. Another analysis of EAs focuses on single-market banks, and finds that these banks reduce their risks in reaction to the EAs, cutting back supplies of credit and liquidity creation (Danisewicz et al., 2018).

Some evidence also suggests that increased microprudential supervision may trigger more market discipline, which may further help reduce bank risks. The research finds that bank market values decline after revelation of examination downgrades (Berger and Davies, 1998) and EAs (Jordan et al., 1999; Roman, 2020). As noted, the findings above of reduced risk from higher capital ratios may also be considered supportive evidence for reduced risk benefits of microprudential supervision.

Thus, the evidence suggests that the increases in microprudential supervision during and after the GFC likely reduced bank risks and helped the banks stay safer during the COVID-19 shock. We add one caveat that the increase in EAs after the GFC was not maintained all the way through to 2020 , so it may be the case that some of the reduced risk benefits from increased supervision may have dissipated by the time of COVID-19.

\subsection{Shift to the Orderly Liquidation Authority (OLA) bail-in resolution regime}

As discussed above, policies for resolution of banks in financial distress ex post also provide ex ante risk-taking incentives for the banks. Under a bailout regime in which banks expect government aid in the event of their financial distress, moral hazard incentives may result in greater risk taking. Such moral hazard incentives are likely reduced under a bail-in regime in which debt holders or other private-sector agents provide the aid and may apply more market discipline to keep bank risks under control.

With the passage of 2010 Dodd-Frank Act and its Orderly Liquidation Authority (OLA) provision, the U.S. officially moved to a bail-in regime for the resolution of large bank holding companies. Under OLA, shareholders of large financial distressed organizations lose their shares and subordinated debtholders or other junior creditors have some or all of their claims turned into equity capital. While it is uncertain whether OLA bail-ins would be invoked instead of bailouts in the event of significant financial distress, the possibility that this may occur can affect ex ante bank risk choices.

Theoretical research suggests that a bail-in regime provides strong incentives for banks to raise equity capital ratios ex ante to reduce the likelihood of shareholders losing their claims in the event of financial distress (Berger et al., 2021c). Empirical research on OLA also suggests that it was successful in terms of increasing the level and speed of adjustment of capital ratios (Berger et al., 2021c). OLA additionally appears to have improved market discipline, putting more risk premiums into bond ratings (Moody's Investor Service, 2013, 2015; Standard and Poor's Rating Services, 2015), and increasing CDS spreads for large banks (Bai et al., 2012). Research on bail-ins in Europe, where the practice is more widespread, is also supportive of the risk-reducing and improved market discipline benefits of bail-ins (e.g., Schafer et al., 2016; Boccuzzi and De Lisa, 2017; Giuliana, 2019; Lindner and Redak, 2017; Bonfim and Santos, 2020; Beck et al., 2021), but some of the benefits may only be short term (Neuberg et al., 2018). Thus, it appears likely that the OLA provision of the Dodd-Frank Act helped fortify the U.S. banking industry in advance of the COVID-19 shock.

\subsection{Suggestions for future research on bank prudential policies}

Overall, the research in Section 5 strongly suggests that the bank prudential policy responses to the GFC helped prepare the U.S. banking industry to be resilient to the COVID-19 crisis. In terms of future research, we recommend further pursuit of this issue with research that specifically ties the performance of individual banks during COVID-19 with some of the prudential changes before the crisis. For example, sensible research agendas would include measure the effects of stress test failures and EAs on individual banks prior to the COVID-19 crisis on their relative performance during the crisis.

\section{Interactions among the "surprises" and the key reasons behind them}

The prior four sections that individually describe the two "surprises" and the key reasons for each are considerably simplified for the purposes 
of exposition. We recognize that the real economy and financial system are interlinked and that the relatively exogenous factors that affect one also affect the other.

In this section, we recognize and discuss some of these interactions. We first briefly discuss how the two "surprises" are related, followed by a short discussion of how the government stimulus programs helped the banks as well as the real economy. We then discuss in more detail the issue of the effects on the real economy of the prudential policies that protected the banking system. This issue is more complex and requires a more in-depth review of the arguments and extant research, including the research on bank credit supplies during the COVID-19 crisis.

\subsection{Interactions between the two "surprises"}

We first note that the "economic surprise" and "financial surprise" are mutually reinforcing. If the economy had collapsed, the loan losses would have depleted the capital of the banks and resulted in a banking crisis. Similarly, if the banking industry had suffered widespread failures or financial distress, the resulting significant pullback in credit supply would have undermined the economic recovery. Thus, the only realistic outcomes of the COVID-19 shocks were that either both or neither of the "surprises" would have occurred.

\subsection{Effects of the government stimulus programs during COVID-19 on the "financial surprise"}

We next briefly acknowledge that the fast and large government stimulus programs that rescued that real economy also helped promote the "financial surprise" of the relatively healthy banks. Without these stimulus programs promoting the real economy, it is likely that there would be many more defaults on bank loans that would have endangered the banks.

In addition, at least one of the stimulus measures, the PPP, also aided the banks both directly and indirectly. Institutions that participated in PPP earned fees between one and five percent for essentially making risk-free loans that require little in the way of monitoring, collection costs, or potential credit losses, given that these loans were not expected to be paid back. The banks may also be indirectly supported because some of their relationship borrowers to whom the banks distributed the PPP funds may be more likely to repay other loans. The PPP may have also generated other banking business from the relationship and nonrelationship recipients, aiding the banks further. The evidence presented in Section 5.2 above suggests that in most cases, PPP banks increased their loan portfolios. Additional findings in the research literature suggest higher bank profitability associated with PPP participation (e.g., Berger et al., 2021d; Marsh and Sharma, 2021), as well as competitive advantages over other banks (e.g., Berger et al., 2021d). We suggest more research on this topic.

\subsection{Effects of the bank prudential policy responses to the GFC on the "economic surprise"}

The more complex issue concerns the effects of the bank prudential policies implemented in response to the GFC on the "economic surprise." Up to some point, these prudential policies, including the four topics reviewed above - higher capital requirements, introduction of stress tests, increased microprudential supervisory scrutiny, and shift to the Orderly Liquidation Authority (OLA) bail-in resolution regime - likely aided the real economy and helped achieve the "economic surprise." By preventing the banking system from significant financial distress, the tighter prudential policies likely averted a substantial credit crunch. That is, they probably prevented a significant decline in credit supplies that would have harmed the real economy when it was already in difficulties due to the public health and government restrictions shocks.

However, beyond some point, the responses of the banks to these tougher prudential policies was almost surely to reduce credit supplies at the margin, which likely hindered short-term economic growth and kept the "economic surprise" from being even greater. We summarize three sets of research findings that bear on the likely extent of these effects - findings on these prudential policies themselves, results on the causes of the U.S. credit crunch and recession of the early 1990s, and research on bank credit supplies other than the PPP effects during the COVID-19 crisis.

\subsubsection{Research on bank prudential policy responses on bank credit supplies and the real economy}

A very straightforward bank response to the tightening of almost any prudential policy would be to reduce credit risk by curtailing credit supply. This applies all four of the bank prudential policy responses to the GFC reviewed above, which we briefly discuss here in order.

7.3.1.1. Higher capital requirements and bank credit supplies and the real economy. Starting with higher capital requirements, the theoretical research findings summarized above strongly suggest that the higher capital ratios brought about by higher capital requirements help offset moral hazard incentives to take on excessive portfolio risks (e.g., Admati et al., 2013; Thakor, 2019), and the empirical bank failure literature (e. g., Cole and Gunther, 1995; others) and empirical financial crisis literature (e.g., Berger and Bouwman, 2013) supports this view. The easiest and fastest method of reducing portfolio risks is to reduce lending, which may also harm the real economy at the margin.

With respect to the implementation of the Basel III capital requirements specifically, there is an additional "mechanical" incentive to reduce lending. Banks can directly increase their risk-based capital ratios under Basel III by attenuating their credit supplies. Fewer loans reduce the risk-weighted assets measures in the denominators of these capital ratios.

7.3.1.2. Introduction of stress tests and bank credit supplies and the real economy. The logic for the introduction of stress tests is similar to that for capital requirements, given that these tests are essentially forwardlooking capital requirements. Reducing credit supply is a very direct way to reduce the likelihood that a simulated adverse future scenario would cause credit losses that would impair a bank's capital. The research evidence is overwhelmingly consistent with this argument. The stress test papers cited above showing risk reductions - Covas (2017); Acharya et al. (2018); Connolly (2018); Berrospide and Edge (2019); Cortés et al. (2020) - unanimously find that stress tests result in credit supply reductions. Such credit supply decreases may harm the real economy at the margin, particularly the reductions found in the supply of small business credit, given that many small businesses are financially constrained.

7.3.1.3. Increased microprudential supervisory scrutiny and bank credit supplies and the real economy. Reducing credit supply is also clearly a rational bank reaction to increased microprudential supervisory scrutiny. The on-site bank examinations that supervisors use to monitor bank risks focus squarely on evaluating credit risks in the loan portfolio by reviewing loan documents. These credit risks are most easily reduced by cutting back credit supplies. As discussed above, the EA papers find that these supervisory actions are effective in reducing portfolio risks, which include reducing credit supplies (Danisewicz et al., 2018; Berger et al., forthcoming). Danisewicz et al. (2018) also provide direct evidence of that EAs that harm the real economy at the margin.

7.3.1.4. Shift to the Orderly Liquidation Authority (OLA) bail-in resolution regime and the real economy. The theoretical evidence provided above suggests that the shift to the OLA bail-in regime would reduce ex ante risk-taking incentives for the banks (Berger et al., 2021c). The empirical evidence also suggests that it did so in terms of capital ratios (Berger et al., 2021c), bond ratings (Moody's Investor Service, 2013, 2015; 
Standard and Poor's Rating Services, 2015), and CDS spreads (Bai et al., 2012). These risk reductions are consistent with, but are not direct evidence of the effects of OLA bail-in implementation resulting in reduced lending and harming the real economy.

The more extensive European empirical research on bail-ins cited above also suggests at least short-term reductions in risk from bail-ins (e. g., Schafer et al., 2016; others), and does provide some evidence that bail-ins reduce bank credit and harm the real economy at the margin. Beck et al. (2021) investigates a European bail-in and finds evidence of a significant reduction in credit supply to financially constrained small firms, reducing their investment and employment.

\subsubsection{Research on bank prudential policies and the U.S. credit crunch and recession of the early $1990 \mathrm{~s}$}

We also draw guidance about the likely effects of the strengthening of bank prudential policies in response to the GFC on credit supplies and the real economy during the COVID-19 crisis by looking back at research on a prior crisis. The U.S. credit crunch and recession of the early $1990 \mathrm{~s}$ provides an example of a well-researched case of the potential effects of a tightening of prudential policies on bank credit supplies and real economy during a crisis and recession.

To set the stage, the first Basel Accord, later known as Basel I, was agreed to in 1988. It was implemented in stages in the U.S., with partial compliance required by December 1990 and full compliance by December 1992. There were also increased explicit and implicit leverage requirements (simple ratios of capital to assets) imposed by regulators and supervisors, respectively, around these times, including the Prompt Corrective Action (PCA) rules of the FDIC Improvement Act (FDICIA) of 1991.

It was also widely believed that bank supervisors became tougher in the late 1980 s and early 1990 s in reaction to the widespread bank capital shortfalls and failures of the late 1980s. Research confirms the increases in supervisory toughness with evidence that bank supervisors assigned worse examination ratings and required greater allocations for loan and lease losses (which reduce reported capital ratios) for a given set of bank conditions during these times (e.g., Bizer, 1993; Berger et al., 2001).

During the early 1990s, banks in the U.S. significantly reduced their commercial lending. There was a drop of $23.2 \%$ in aggregate bank commercial and industrial (C\&I) loans during the first three years of the 1990s based a comparison of Call Report data from 1989:Q4 with 1992: Q4 (Berger et al., 1995). Although some of the decline may be due to reduced credit demand, the massive size of the drop and the fact that it corresponds with a period of significant bank distress means that there was almost surely a credit crunch, or significant reduction in credit supply.

The extent to which the credit crunch harmed the real economy depends in large part on alternative opportunities of the potential borrowers. Large businesses more often have alternative sources of external finance, while small businesses are more often bank-dependent and face financial constraints. Call Reports at that time reported no information on loan or firm size, but one study combines the Call Report data with information from the Federal Reserve's Survey of Terms of Bank Lending to Business (STBL) to try to differentiate the effects by firm size. The authors' estimates suggest much more severe credit cuts for small businesses - reductions of $38.5 \%$ in loans to firms with less than $\$ 1$ million in bank credit, and $45.2 \%$ for small business borrowers with credit below \$250,000 (Berger et al., 1995, Tables 8, A2, A8, A10). It seems very likely from these results that the credit crunch had significant negative real economic consequences and contributed to the recession.

A significant amount of banking research focuses on whether the toughening of bank prudential policies helped cause the credit crunch. Some test the effects of implementation of the Basel I risk-based capital requirements (e.g., Haubrich and Wachtel, 1993; Berger and Udell, 1994; Hancock and Wilcox, 1994; Wagster, 1999), and some test the effects of higher explicit (regulatory) or implicit (supervisory) capital standards based on leverage ratios (e.g., Berger and Udell, 1994; Peek and Rosengren, 1994, 1995; Hancock and Wilcox, 1994; Hancock et al., 1995; Shrieves and Dahl, 1995). It is difficult to differentiate between them, but the research provides more support for the leverage standards and relatively little support for the role of the Basel I risk-based capital requirements.

Other papers test whether the tougher supervisory standards imposed during bank examinations resulted in reduced lending. Bizer (1993) and Berger et al. (2001) both find that the tougher standards caused reductions in credit supply, but the latter study concludes that the effects were relatively small economically.

Thus, the research on the credit crunch of the early 1990s suggests that the strengthening of bank prudential policies was likely responsible for only a small portion of the credit crunch and harm to the real economy at that time. It seems likely more of the declines in lending were due to other causes, such as the financial distress of the banks at that time.

\subsubsection{Research on bank credit supplies other than the PPP effects and the} real economy during the COVID-19 crisis

We finally turn to the research evidence on bank credit supplies other than PPP effects during the COVID-19 crisis. If it is the case that bank prudential policy responses to the GFC resulted in marginal decreases in credit supply that may have marginally inhibited the "economic surprise," they should be apparent in decreases in bank credit supplies during the crisis other than the effects of the PPP. We specifically exclude the PPP effects on bank lending because these are from a different cause than the prudential policies.

Near the beginning of the crisis in March 2020, many large U.S. corporations participated in the "dash for cash" referenced above in which they drew down their existing revolvers or credit lines from large banks (e.g., Acharya and Steffen, 2020; Greenwald et al., 2020; Li et al., 2020; Acharya et al., 2021; Chodorow-Reich et al., forthcoming). This may be viewed primarily as an increase in the demand for credit due to worries about deteriorations in either their own conditions or those of the banks, rather than a change in credit supply by the banks, since banks are contractually obligated to honor their prior commitments. A similar phenomenon occurred during the GFC (e.g., Ivashina and Scharfstein, 2010). However, the "dash for cash" may have been somewhat limited by credit supply to the extent that some banks exercised material adverse change clauses or stepped up enforcement of covenants, which may help explain why small firms had relatively little participation in this phenomenon (e.g., Chodorow-Reich et al., forthcoming).

Nevertheless, the "dash for cash" could potentially affect bank credit supply. The credit line drawdowns raised the banks' liquidity and credit risks, and so may have resulted in reductions in bank credit supply. Several studies find these reactions, reduced credit supply to other borrowers (e.g., Greenwald et al., 2020; Acharya et al., 2021; Kapan and Minoiu, 2021). Importantly, this particular evidence related to the "dash for cash" does not provide significant support for or against the notion that bank prudential policy responses to the GFC may have reduced credit supply and marginally inhibited the "economic surprise" because these changes in supply are directly related to a different cause.

The Beck and Keil (2021) paper cited above which finds that banks more exposed to the COVID-19 economic consequences had performance issues also finds that these banks reduced SME lending other than PPP loans, and also reduced lending overall inclusive of PPP loans, which could have hindered the "economic surprise" at the margin. In contrast, Levine et al. (2020) find evidence that credit supplies by small banks may have aided the "surprise" at the margin with countercyclical funding to small firms that improved employment relative to what it otherwise might have been.

There is also some limited evidence on the supply of credit card debt. Examining Y-14M credit card data from the Federal Reserve for credit 
cards up to August 2020, Horvath et al. (2021) show increases in the interest rates of new credit cards to less creditworthy consumers, consistent with a tightening of credit supply and a flight-to-safety response of banks to the COVID-19 shock.

We also review some research results for the relative effects of the COVID-19 on relationship versus non-relationship borrowers for both conventional commercial credit and credit card debt for both consumers and small businesses. Berger et al. (2021a) find that conventional commercial relationship borrowers fare significantly worse than non-relationship borrowers in their loan contract terms (spread, collateral, maturity, amount) in response to COVID-19 shocks, contrary to findings for normal times (e.g., Kysucky and Norden, 2016) and prior crises (e.g., Bolton et al., 2016). The results are more pronounced for larger firms and larger banks. Berger et al. (2021b) also find different effects for credit cards for consumers and small businesses. During COVID-19, both groups benefit with better contract terms, with more benefits flowing to safer relationship customers.

It is difficult to draw strong conclusions about credit supply from the relative credit terms of relationship versus non-relationship borrowers. The conventional commercial credit results of relatively worse loan contract terms for relationship borrowers may reflect that banks reduced credit supply to relationship borrowers to "hold up" these borrowers when the value of soft information from relationships is relatively high (e.g., Sharpe, 1990; Rajan, 1992). Alternatively, these banks may try to bolster their capital in the crisis with earnings from the higher spreads and other harsher credit terms that they cannot charge non-relationship borrowers. The findings may also reflect increases in supply to non-relationship borrowers to try to gain market shares in turbulent times. Similarly, the relatively beneficial effects of the crisis on contract terms for credit card consumers and small business customers is ambiguous.

Finally, we briefly review extant research on COVID-19 bank credit supply changes from international or non-U.S. studies, despite the fact that they do not provide direct evidence on whether bank credit decisions hindered the "economic surprise" in the U.S. Non-U.S. studies of bank credit supply changes during COVID-19 is valuable evidence on its own of bank reactions to essentially the same crisis, and may give valuable information about bank behavior in the U.S. as well.

A number of cross-country studies find the COVID-19 crisis resulted in tougher credit conditions for borrowers. They faced higher loan spreads at the intensive margin (Hasan et al., 2021b), and received lower credit quantities at the extensive margin (Colak and Oztekin, 2021; Dursun-de Neef and Schandlbauer, 2021; Park and Shin, 2021), with some key differences about which borrowers suffered the worst credit reductions. ${ }^{35}$ Some of these differences in credit conditions are due to variations in how COVID-19 affected credit risks. Some research suggests that corporate CDS spread reactions to the pandemic, which reflect these credit risks, vary in systematic ways with firm, debt, and industry characteristics as well as national policies (e.g., Liu et al., 2021; Hasan et al., 2021a).

One study of bank credit supply in Brazil illustrates the effects of different types of government policies. Norden et al. (2021) show that credit supply in the nation decreased during the COVID-19 crisis, but that the effects may be moderated or aggravated by government policy interventions. "Soft interventions," such as social distancing and mass gathering restrictions moderate the credit supply shocks and "hard interventions," such as closures of public venues and non-essential services aggravate the shocks.

\footnotetext{
35 In some cases, these additional borrowing difficulties may have been offset to some degree by asset values gains from holdings of "safe haven" currencies that appreciated during the COVID-19 crisis, especially the U.S. dollar (e.g., Hale and Juvenal, 2021).
}

7.3.4. Conclusions from the research on the effects of the bank prudential policy responses to the GFC on the "economic surprise"

The research reviewed here on the extent to which the bank prudential policies implemented in response to the GFC may have significantly inhibited the "economic surprise" at the margin by reducing credit supply is extensive, but largely inconclusive. The research findings on these prudential policies themselves are suggestive of large reductions in credit supply during normal times, but may not necessarily hold in a crisis. The results of similar policy tightenings during a prior crisis - the U.S. credit crunch and recession of the early 1990s - suggest modest effects, but may not be conclusive regarding COVID-19 because the crises are so different. Finally, the research on bank credit supplies other than the PPP effects during the COVID-19 crisis mostly, but not entirely, suggest credit supply reductions at the margin, but much more research on this issue is needed.

\section{Conclusions and additional future research directions}

Crises are devastating events and COVID-19 has had very substantial human and economic tolls. Ironically, crises also represent significant research opportunities for us to learn from the experiences. Crises provide chances to learn what works by offering opportunities to observe failures. Crises also generate new government policies to research, and deliver exogenous shocks to use as quasi-natural experiments to tackle new and old research questions. As a consequence, many years of consequential economic and financial research often follow. Given that COVID-19 features all of these properties and is unique among crises in several dimensions as well, we may expect a strong pipeline of research to come over a long period of time, not only in banking, economics, and finance, but on all fronts, including other business and social science topics. The earlier sections of this paper suggest that a number of research papers are in process, forthcoming, and published, and also provide suggestions for future research. We add to this list of suggestions here.

Studying the numerous policy approaches employed in the COVID19 crisis is likely to be particularly fruitful. There were many different policy measures implemented across the world that impacted bank lending decisions, the banks themselves, and real economic outcomes. As discussed above, there is an active research agenda on these topics in the U.S., but much more can be accomplished across the world. Examining policy measures and bank-level data over time and across countries will likely reveal many important lessons, particularly since researchers tend to learn more where failures occur. Initial findings suggest the impact of policy interventions adopted in different countries have been mixed, and depend on bank and country characteristics. As more detailed bank-level data become available across the world, we can observe how banks behaved during the crisis; to what extent they lent to corporations, small firms, and households; and how banks with different size and ownership characteristics - large versus small banks, and private domestic- versus foreign- versus state-owned banks behaved differently, and how these dynamics varied across countries.

While we have not observed bank runs or market crashes around the world, if economic recovery is not as swift as in the U.S., and banks in other nations were not as well capitalized and fortified entering the crisis, they may experience deteriorations in their asset quality that eventually leads to deleveraging and credit crunches that can slow the recoveries in their countries. Fiscal and financial pressures may also necessitate that countries reduce their fiscal and monetary supports and wind down their forbearance measures, creating potential vulnerabilities that will need to be carefully monitored.

If deterioration of asset quality happens, how to best repair this damage will be an important topic. For example, what market-based solutions will be available to deal with banks' troubled assets? Are there circumstances under which public intervention, whether targeted or broad, is needed to deal with nonperforming loans? Since insolvency and resolution frameworks are important to speed up the reduction of 
nonperforming loans, research providing guidance from successful debt restructuring schemes and insolvency reforms may become quite important.

The pressures on governments brought on by their extraordinary largess and reduced tax revenues during the COVID-19 crisis also raise further policy concerns and issues for researchers to monitor carefully at the national level. We observed the European Sovereign Debt Crisis running on for several years after the GFC. Some nations, particularly the GIIPS countries, experienced crippling deficits related to bank bailouts and recessions and in some cases required sovereign bailouts that came with strings attached. It remains possible that the governments of some nations may need to significantly reduce their expenditures, raise their taxes, or require outside assistance again after COVID19. These are unwelcome developments that policy makers may have to contend with and may provide valuable research opportunities to study.

Another related topic for future research is the impact of bank lending during COVID-19 on the real economy. As in the U.S., it will be important to investigate the experience of different countries to see if additional bank lending helped firms to avoid closures and retain employment and whether this lending aided healthy versus zombie firms. What was the experience after government support measures were discontinued? Did the timing and manner in which this winding down occurred determine the extent and impact of any resulting contraction? The role of credit factors in the decisions of households, firms, and particularly financial intermediaries during, and even more so, after the pandemic is likely to be another promising research avenue.

Another fruitful area to examine is the impact of COVID-19 on longer-term structural issues. Under this broad area, one interesting topic is whether the crisis has impacted bank operations and business models. While digitalization and FinTech were significant trends predating the crisis, it is important to determine if the crisis accelerated these trends, given how prominent digital services became during the pandemic. Has the pandemic accelerated the trend away from brick-andmortar banking and move to on-line services? One study suggests that COVID-19 very substantially accelerated the adoption of FinTech platforms in payments, but much more research is needed (Tut, 2020). Another research paper suggests that COVID-19 had important effects on on-line trading for retail investors using Robinhood, which may draw funds away from conventional brick-and-mortar banking (Pagano et al., 2021).

Another longer-term research question is whether and how the COVID-19 crisis will impact banking market structure. There has been significant prior research and policy discussions about how globalization and technological change have been leading to increasing levels of market power and concentration in the corporate sector. After the crisis, these worries have intensified, since failures of small firms and government support to larger corporations may have further increased market concentration, eroding competition in the real sector and hampering inclusive recovery. Similarly, it would be interesting to explore the companion trends in the banking sector. Will we see a more concentrated banking sector around the world after COVID-19, consolidating power and reducing efficiency? Or since digital services and mobile banking gained so much traction during the crisis, will the banking industry face increased contestability due to competitive pressures from FinTech and technology-savvy banking players?

Finally, COVID-19 also reinforced the concerns around climate change, as a way to increase resilience to future shocks, as well as reduce risks. There is now increasing recognition around the world that climate change is a global emergency, and that building green objectives into COVID-19 recovery packages is a priority. Importantly, sustainable policies also need to make economic sense, and financial institutions will be important in financing the investments required for green transition. Indeed, emerging research already suggests that credit constraints are important barriers that may prevent corporations from reducing their carbon footprints. Central banks around the world are working on assessing climate risks, and financial institutions are already re- orienting investments toward green projects. In the post-COVID-19 world, the impacts and implications of these developments for the banking industry will be key topics of future research.

\section{References}

Abboud, A., Duncan, E., Horvath, A., Iercosan, D., Loudis, B., Martinez, F., Mooney, T., Ranish, B., Wang, K., Warusawitharana, M., Wix, C., 2021. COVID-19 as a stress test: assessing the bank regulatory framework. Working Paper.

Acharya, V., Berger, A.N., Roman, R.A., 2018. Lending implications of US bank stress tests: costs or benefits? J. Financ. Intermed. 34, 58-90.

Acharya, V., Engle III, R.F., Steffen, S., 2021. Why did bank stocks crash during COVID19 ? Working Paper.

Acharya, V., Naqvi, H., 2012. The seeds of a crisis: a theory of bank liquidity and risk taking over the business cycle. J. Financ. Econ. 106, 349-366.

Acharya, V., Steffen, S., 2020. The risk of being a fallen angel and the corporate dash for cash in the midst of COVID. Rev. Corp. Financ. Stud. 9, 430-471.

Adams, R.M., Bord, V., 2021. Cardiac myosin activation with omecamtiv mecarbil in systolic heart failure. N. Engl. J. Med. 384, 105-116.

Admati, A.R., DeMarzo, P.M., Hellwig, M.F., Pfleiderer, P.C., 2013. Fallacies, irrelevant facts, and myths in the discussion of capital regulation: why bank equity is not socially expensive. SSRN Electron. J. 23.

Adolph, C., Amano, K., Bang-Jensen, B., Fullman, N., Wilkerson, J., 2021. Pandemic politics: timing state-level social distancing responses to COVID-19. J. Health Polit. Policy Law 46, 211-233.

Agarwal, S., An, X., Cordell, L., Roman, R.A., 2021. Bank stress tests results and their impact on consumer credit markets. Working Paper.

Amiram, D., Rabetti, D., 2020. The relevance of relationship lending in times of crisis Working Paper.

Anginer, D., Bertay, A.C., Cull, R., Demirgüç-Kunt, A., Mare, D.S., 2021. Bank capital regulation and risk after the Global Financial Crisis. J. Financ. Stab., 100891

Anginer, D., Demirgüç-Kunt, A., 2019. Bank runs and moral hazard: a review of deposit insurance. In: Berger, A.N., Molyneux, P., Wilson, J.O.S. (Eds.), Oxford Handbook of Banking, third ed. Oxford University Press, Oxford.

Armantier, O., Ghysels, E., Sarkar, A., Shrader, J., 2015. Discount window stigma during the 2007-2008 financial crisis. J. Financ. Econ. 118, 317-335.

Assaf, A.G., Berger, A.N., Roman, R.A., Tsionas, M.G., 2019. Does efficiency help banks survive and thrive during financial crises? J. Bank. Financ. 106, 445-470.

Atkinson, T., Luttrell, D., Rosenblum, H., 2013. How bad was it? The costs and consequences of the 2007-09 financial crisis. Working Paper.

Atkins, R., Cook, L.D., Seamans, R., forthcoming. Discrimination in lending? Evidence from the Paycheck Protection Program. Small Bus. Econ.

Autor,D., Cho, D., Crane, L., Goldar, M., Lutz, B., Montes, J., Peterman, W., Ratner,D., Villar, D., and Yildirmaz, A., 2020. An evaluation of the PaycheckProtection Program using administrative payroll microdata. Working Paper.

Bai, J., Cabanilla, C., Middledorp, M., 2012. The new bank resolution regimes and "Toobig-to-fail." Federal Reserve Bank of New York Liberty Street Economics.

Balyuk, T., Prabhala, N.R., Puri, M., 2021. Small bank financing and funding hesitancy in a crisis: evidence from the Paycheck Protection Program. Working Paper.

Barrazza, S., Rossi, M.A., Yeager, T.J., 2020. The short-term effect of the Paycheck Protection Program on unemployment. Working Paper.

Barth, J.R., Caprio, G., Levine, R., 2006. The design and governance of bank supervision, in: Riksbank Conference on the Governance of Central Banks.

Bartik, A.W., Cullen, Z.B., Glaeser, E.L., Luca, M., Stanton, C.T., Sunderam, A., 2020. The targeting and impact of Paycheck Protection Program loans to small businesses. Working Paper.

Bartlett III, R.P., Morse, A., forthcoming. Small business survival capabilities and policy effectiveness: evidence from Oakland. J. Financ. Quant. Anal.

Beck, T., Da-Rocha-Lopes, S., Silva, A.F., 2021. Sharing the pain? Credit supply and real effects of bank bail-ins. Rev. Financ. Stud. 34, 1747-1788.

Beck, T., Keil, J., 2021. Are banks catching corona? Effects of COVID on lending in the US. Working Paper.

Berger, A.N., 1995. The relationship between capital and earnings in banking. J. Money Credit Bank. 27, 432-456.

Berger, A.N., 2018. The benefits and costs of the TARP bailouts: a critical assessment. Q. J. Financ. 08, 1850011.

Berger, A.N., Black, L.K., Bouwman, C.H.S., Dlugosz, J., 2017. Bank loan supply responses to Federal Reserve emergency liquidity facilities. J. Financ. Intermed. 32, $1-15$.

Berger, A.N., Bouwman, C.H.S., 2013. How does capital affect bank performance during financial crises? J. Financ. Econ. 109, 146-176.

Berger, A.N., Bouwman, C.H.S., 2017. Bank liquidity creation, monetary policy, and financial crises. J. Financ. Stab. 30, 139-155.

Berger, A.N., Bouwman, C.H.S., Norden, L., Roman, R.A., Udell, G.F., Wang, T., 2021a. Is a friend in need a friend indeed? How relationship borrowers fare during the COVID19 crisis. Working Paper.

Berger, A.N., Bouwman, C.H.S., Norden, L., Roman, R.A., Udell, G.F., Wang, T., 2021b. Piercing through opacity: relationships and credit card lending to consumers and small businesses during normal times and the COVID-19 crisis. Working Paper.

Berger, A.N., Cai, J., Roman, R.A., Sedunov, J., forthcoming. Supervisory enforcement actions against banks and systemic risk. J. Bank. Financ.

Berger, A.N., Davies, S.M., 1998. The information content of bank examinations. J. Financ. Serv. Res. 14, 117-144. 
Berger, A.N., Davies, S.M., Flannery, M.J., 2000. Comparing market and supervisory assessments of bank performance: who knows what when? J. Money Credit Bank. 32, 641-667.

Berger, A.N., DeYoung, R., Flannery, M.J., Lee, D., Öztekin, Ö., 2008. How do large banking organizations manage their capital ratios? J. Financ. Serv. Res. 34, 123-149.

Berger, A.N., Epouhe, O., Roman, R.A., 2021a. A tale of two bailouts: effects of TARP and PPP on subprime consumer debt. Working Paper.

Berger, A.N., Freed, P.G., Scott, J.A., Zhang, S., 2021b. The Paycheck Protection Program (PPP) from the small business perspective: did the PPP help alleviate financial and economic constraints? Working Paper.

Berger, A.N., Herring, R.J., Szegö, G.P., 1995. The role of capital in financial institutions. J. Bank. Financ. 19, 393-430.

Berger, A.N., Himmelberg, C.P., Roman, R.A., Tsyplakov, S., 2021c. Bank bailouts, bailins, or no regulatory intervention? A dynamic model and empirical tests of optimal regulation. Working Paper.

Berger, A.N., Imbierowicz, B., Rauch, C., 2016. The roles of corporate governance in bank failures during the recent financial crisis. J. Money Credit Bank. 48, 729-770.

Berger, A.N., Karakaplan, M.U., Roman, R.A., 2021d. Whose bailout is it anyway? Political connections of small businesses vs. banks in PPP bailouts. Working Paper.

Berger, A.N., Kyle, M.K., Scalise, J.M., 2001. Did US bank supervisors get tougher during the credit crunch? Did they get easier during the banking boom? Did it matter to bank lending?. In: National Bureau of Economic Research. University of Chicago Press, pp. 301-356.

Berger, A.N., Lamers, M., Roman, R.A., Schoors, K., 2021e. Unexpected effects of bank bailouts: depositors need not apply or worry. Working Paper.

Berger, A.N., Makaew, T., Roman, R.A., 2019. Do business borrowers benefit from bank bailouts?: The effects of tarp on loan contract terms. Financ. Manag. 48, 575-639.

Berger, A.N., Molyneux, P., Wilson, J.O.S., 2020a. Banks and the real economy: an assessment of the research. J. Corp. Financ. 62, 101513.

Berger, A.N., Roman, R.A., 2015. Did TARP banks get competitive advantages? J. Financ. Quant. Anal. 50, 1199-1236.

Berger, A.N., Roman, R.A., 2017. Did saving Wall Street really save Main Street? The rea effects of TARP on local economic conditions. J. Financ. Quant. Anal. 52, 1827-1867.

Berger, A.N., Roman, R.A., 2020. TARP and Other Bank Bailouts and Bail-ins Around the World: Connecting Wall Street, Main Street, and the Financial System. Academic Press.

Berger, A.N., Roman, R.A., Sedunov, J., 2020b. Did TARP reduce or increase systemic risk? The effects of government aid on financial system stability. J. Financ. Intermed. 43, 100810.

Berger, A.N., Udell, G.F., 1994. Did risk-based capital allocate bank credit and cause a' credit crunch" in the United States? J. Money Credit Bank. 26, 585-628.

Berger, A.N., Udell, G.F., 2004. The institutional memory hypothesis and the procyclicality of bank lending behavior. J. Financ. Intermed. 13, 458-495.

Bernanke, B.S., 1983. Nonmonetary effects of the Financial Crisis in the propagation of the Great Depression. Am. Econ. Rev. 73, 257-276.

Berrospide, J.M., Edge, R.M., 2019. The effects of bank capital buffers on bank lending and firm activity: what can we learn from five years of stress-test results? Working Paper.

Bizer, D.S., 1993. Regulatory discretion and the credit crunch. Working paper, U.S. Securities and Exchange Commission.

Black, L.K., Hazelwood, L.N., 2013. The effect of TARP on bank risk-taking. J. Financ. Stab. 9, 790-803.

Blau, B.M., Brough, T.J., Thomas, D.W., 2013. Corporate lobbying, political connections, and the bailout of banks. J. Bank. Financ. 37, 3007-3017.

Boccuzzi, G., De Lisa, R., 2017. Does bail-in definitely rule out bailout? J. Financ. Manag. Mark. Inst. 93-110.

Bolton, P., Freixas, X., Gambacorta, L., Mistrulli, P.E., 2016. Relationship and transaction lending in a crisis. Rev. Financ. Stud. 29, 2643-2676.

Bonfim, D., Santos, J.A.C., 2020. The importance of deposit insurance credibility. Working Paper.

Calabrese, R., Degl'Innocenti, M., Osmetti, S.A., 2017. The effectiveness of TARP-CPP on the US banking industry: a new copula-based approach. Eur. J. Oper. Res. 256, 1029-1037.

Calem, P., Rob, R., 1999. The impact of capital-based regulation on bank risk-taking. J. Financ. Intermed. 8, 317-352.

Calomiris, C.W., Khan, U., 2015. An assessment of TARP assistance to financial institutions. J. Econ. Perspect. 29, 53-80.

Cao-Alvira, J.J., Núñez-Torres, A., 2019. On TARP and agency securitization. Int. Financ. $22,186-200$.

Chavaz, M., Rose, A.K., 2019. Political borders and bank lending in post-crisis America. Rev. Financ. 23, 935-959.

Chen, H., Yeh, C., 2020. Global financial crisis and COVID-19: industrial reactions. Financ. Res. Lett.

Chetty, R., Friedman, J., Hendren, N., Stepner, M., 2020. How did covid-19 and stabilization policies affect spending and employment? A new real-time economic tracker based on private sector data. NBER Working Paper.

Chodorow-Reich, G., Darmouni, O., Luck, S., Plosser, M.C., forthcoming. Bank liquidity provision across the firm size distribution. J. Financ. Econ.

Cole, R.A., Gunther, J.W., 1995. Separating the likelihood and timing of bank failure. J. Bank. Financ. 19, 1073-1089.

Cole, R.A., Gunther, J.W., 1998. Predicting bank failures: a comparison of on-and off-site monitoring systems. J. Financ. Serv. Res. 13, 103-117.

Cole, R.A., White, L.J., 2012. Déjà vu all over again: the causes of US commercial bank failures this time around. J. Financ. Serv. Res. 42, 5-29.

Connolly, M., 2018. The real effects of stress testing. Working Paper.
Contreras, S., Delis, M.D., Ghosh, A., Hasan, I., 2021a. Bank failures, local business dynamics, and government policy. Small Bus. Econ. 1-29.

Contreras, S., Ghosh, A., Kong, J.H., 2021b. Financial crisis, bank failures, and corporate innovation. J. Bank. Financ. 129, 106161.

Cortés, K.R., Demyanyk, Y., Li, L., Loutskina, E., Strahan, P.E., 2020. Stress tests and small business lending. J. Financ. Econ. 136, 260-279.

Covas, F., 2017. The capital allocation inherent in the Federal Reserve's capital stress test. Research Note, January 31.

Crane, L.D., Decker, R.A., Flaaen, A., Hamins-Puertolas, A., Kurz, C., 2021. Business exit during the COVID-19 pandemic: non-traditional measures in historical context. Working Paper.

Cyree, K.B., Griffiths, M.D., Winters, D.B., 2013. Federal Reserve financial crisis lending programs and bank stock returns. J. Bank. Financ. 37, 3819-3829.

Danisewicz, P., McGowan, D., Onali, E., Schaeck, K., 2018. The real effects of banking supervision: evidence from enforcement actions. J. Financ. Intermed. 35, 86-101.

Delis, M.D., Savva, C., Theodossiou, P., 2021. The impact of the coronavirus crisis on the market price of risk. J. Financ. Stab. 53, 100840.

Demirgüç-Kunt, A., Lokshin, M., Torre, I., 2021a. The sooner the better: the economic impact of non-pharmaceutical interventions during the early stage of the COVID-19 Pandemic. The Economics of Transition and Institutional Change.

Demirgüç-Kunt, A., Pedraza, A., Ruiz-Ortega, C., 2021b. Banking sector performance during the COVID-19 crisis. J. Bank. Financ. 106305.

DeYoung, R.E., Hughes, J.P., Moon, C.-G., 2001. Efficient risk-taking and regulatory covenant enforcement in a deregulated banking industry. J. Econ. Bus. 53, 255-282.

DeYoung, R., Torna, G., 2013. Nontraditional banking activities and bank failures during the financial crisis. J. Financ. Intermed. 22, 397-421.

Didier, T., Huneeus, F., Larrain, M., Schmukler, S., 2021. Financing firms in hibernation during the COVID-19 pandemic. J. Financ. Stab. 53, 100837.

Ding, W., Levine, R., Lin, C., Xie, W., 2021. Corporate immunity to the COVID-19 pandemic. J. Financ. Econ. 141, 802-830.

Duan, Y., Ghoul, S., El, Guedhami, O., Li, H., Li, X., 2021. Bank systemic risk around COVID-19: a cross-country analysis. J. Bank. Financ. 133.

Duchin, R., Hackney, J., forthcoming. Buying the vote? The economics of electoral politics and small business loans. J. Financ. Quant. Anal.

Duchin, R., Sosyura, D., 2012. The politics of government investment. J. Financ. Econ. 106, 24-48.

Duchin, R., Sosyura, D., 2014. Safer ratios, riskier portfolios: banks' response to government aid. J. Financ. Econ. 113, 1-28.

Dursun-de Neef, H.Ö., Schandlbauer, A., 2021. COVID-19 and bank loan supply. Working Paper.

Erel, I., Liebersohn, J., 2020. Does FinTech substitute for banks? Evidence from the Paycheck Protection Program. Working Paper.

Feyen, E., Gispert, T.A., Kliatskova, T., Mare, D.S., 2021. Financial sector policy response to COVID-19 in emerging markets and developing economies. J. Bank. Financ., 106184

Flanagan, T., Purnanandam, A., 2021. Did banks pay "fair" returns to taxpayers on TARP?. Working Paper.

Forssbæck, J., Nielsen, C.Y., 2016. TARP and market discipline: evidence on the moral hazard effects of bank recapitalizations. Working Paper.

Freixas, X., Rochet, J.-C., 2008. Microeconomics of Banking. MIT Press.

Friedman, M., Schwartz, A.J., 1963. A Monetary History of the United States, 1867-1960. Princeton University Press.

Giuliana, R., 2019. Impact of bail-in on banks' bond yields and market discipline. Working Paper.

Goel, A.M., Thakor, A.V., 2020. Pandemic Death Traps. Working Paper.

Goldstein, I., Sapra, H., 2014. Should banks' stress test results be disclosed? An analysis of the costs and benefits. Found. Trends Financ. 8, 1-54.

Granja, J., Makridis, C., Yannelis, C., Zwick, E., 2020. Did the Paycheck Protection Program hit the target? Working Paper.

Greenspan, 2001. The worst loans are made at the top of the business cycle. Chicago Bank Structure Conference May 10, 2001.

Greenwald, D.L., Krainer, J., Paul, P., 2020. The credit line channel. Working Paper.

Griffin, J.M., Kruger, S., Mahajan, P., 2021. Did FinTech lenders facilitate PPP fraud?. Working Paper.

Gunther, J.W., Moore, R.R., 2003. Loss underreporting and the auditing role of bank exams. J. Financ. Intermed. 12, 153-177.

Hale, G., Juvenal, L., 2021. External balance sheets and the COVID-19 crisis. Working Paper.

Hale, T., Petherick A., Phillips T., Webster S., 2020. Variation in government responses to COVID-19. Working Paper.

Hancock, D., Laing, A.J., Wilcox, J.A., 1995. Bank capital shocks: dynamic effects on securities, loans, and capital. J. Bank. Financ, 19, 661-677.

Hancock, D., Wilcox, J.A., 1994. Bank capital and the credit crunch: the roles of riskweighted and unweighted capital regulations. Real Estate Econ. 22, 59-94.

Han, J., Meyer, B.D., Sullivan, J.X., 2020. Income and poverty in the COVID-19 pandemic. Working Paper.

Hasan, I., Marra, M., To, T., Wu, E., Zhang, G., 2021a, COVID-19 pandemic and global corporate CDS spreads, Working Paper.

Hasan, I., Politsidis, P.N., Sharma, Z., 2021b. Global syndicated lending during the COVID-19 pandemic. J. Bank. Financ., 106121

Haubrich, J.G., Wachtel, P., 1993. Capital requirements and shifts in commercial bank portfolios. New York University Salomon Center, Leonard N. Stern School of Business.

Helwege, J., Boyson, N.M., Jindra, J., 2017. Thawing frozen capital markets and backdoor bailouts: evidence from the Fed's liquidity programs. J. Bank. Financ. 76, 92-119. 
Horvath, A., Kay, B., Wix, C., 2021. The covid-19 shock and consumer credit: evidence from credit card data. Finance and Economics Discussion Series 2021-008, Board of Governors of the Federal Reserve System.

Hubbard, R.G., Strain, M.R., 2020. Has the Paycheck Protection Program succeeded? National Bureau of Economic Research Working Paper 28032.

Humphries, J.E., Neilson, C.A., Ulyssea, G., 2020. Information frictions and access to the Paycheck Protection Program. J. Public Econ. 190, 104244.

International Monetary Fund, 2020. Policy responses to COVID-19. 〈https://www.imf. org/en/Topics/imf-and-covid19/Policy-Responses-to-COVID-19).

Ivashina, V., Scharfstein, D., 2010. Bank lending during the financial crisis of 2008. J. Financ. Econ. 97, 319-338.

Iwanicz-Drozdowska, M., Rogowicz, K., Kurowski, L., Smaga, P., 2021. Two decades of contagion effect on stock markets: which events are more contagious? J. Financ. Stab. 55, 100907.

James, C.M., Lu, J., Sun, Y., 2021. Time is money: real effects of relationship lending in a crisis. J. Bank. Financ. 133.

Jang, K.Y., 2017. The effect of TARP on the propagation of real estate shocks: evidence from geographically diversified banks. J. Bank. Financ. 83, 173-192.

Joaquim, G., Netto, F., 2021. Bank incentives and the impact of the Paycheck Protection Program. Working Paper.

John, K., Li, J., 2021. COVID-19, volatility dynamics, and sentiment trading. J. Bank. Financ., 106162

Jordan, J.S., Peek, J., Rosengren, E.S., 1999. Impact of greater bank disclosure amidst a banking crisis.

Kapan, T., Minoiu, C., 2021. Liquidity insurance vs. credit provision: evidence from the COVID-19 crisis. Working Paper.

Karakaplan, M.U., 2021. This time is really different: the multiplier effect of the Paycheck Protection Program (PPP) on small business bank loans. J. Bank. Financ. 133.

Kim, D., Santomero, A.M., 1988. Risk in banking and capital regulation. J. Financ. 43, 1219-1233.

Koehn, M., Santomero, A.M., 1980. Regulation of bank capital and portfolio risk. J. Financ. 35, 1235-1244.

Kohn, D., 2020. COVID-19 and the Banks. Brookings Institution.

Koont, N., Walz, S., 2021. Bank credit provision and leverage constraints: evidence from the supplementary leverage ratio. CEPR Covid Econ. Pap. 72, 1-23.

Kysucky, V., Norden, L., 2016. The benefits of relationship lending in a cross-country context: a meta-analysis. Manag. Sci. 62, 90-110.

Lembo Stolla, S., 2021. Experian 2020 consumer credit review.

Levine, R., Lin, C., Tai, M., Xie, W., forthcoming. How did depositors respond to COVID19 ? Rev. Financ. Stud.

Levine, R., Lin, C., Xie, W., 2020. Local financial structure and economic resilience. Working paper.

Li, L., 2013. TARP funds distribution and bank loan supply. J. Bank. Financ. 37, 4777-4792.

Lindner, P., Redak, V., 2017. The resilience of households in bank bail-ins. Financial Stability Report, Oesterreichische Nationalbank 88-101.

Lin, Y., Liu, X., Srinivasan, A., 2017. Unintended consequences of government bailouts: evidence from bank-dependent borrowers of large banks. Working Paper.

Liu, Y., Qiu, B., Wang, T., 2021. Debt rollover risk, credit default swap spread and stock returns: evidence from the COVID-19 crisis. J. Financ. Stab. 53, 100855.

Li, L., Strahan, P., forthcoming. Who supplies PPP loans (and does it matter)? Banks, relationships and the COVID crisis. J. Financ. Quant. Anal.

Li, L., Strahan, P.E., Zhang, S., 2020. Banks as lenders of first resort: evidence from the COVID-19 crisis. Rev. Corp. Financ. Stud. 9, 472-500.

Lopez, J.A., Spiegel, M.M., 2021. Small business lending under the PPP and PPPLF programs," Federal Reserve Bank of San Francisco Working Paper 2021-10. https:// doi.org/10.24148/wp2021-10.

Lucas, D., 2019. Measuring the cost of bailouts. Annu. Rev. Financ. Econ. 11, 85-108.

Marsh, W.B., Sharma, P., 2021. Government loan guarantees during a crisis: the effect of the PPP on bank lending and profitability. Working Paper.

Minoiu, C., Zarutskie, R., Zlate, A., 2021. Motivating banks to lend? Credit spillover effects of the Main Street lending program. Working Paper.

Modigliani, F., Miller, M.H., 1958. The cost of capital, corporation finance and the theory of investment. Am. Econ. Rev. 48, 261-297.

Muecke, C., Pelizzon, L., Pezone, V., Thakor, A., 2021. The carrot and the stick: bank bailouts and the disciplining role of board appointments, Working paper.

Neuberg, R., Glasserman, P., Kay, B., Rajan, S., 2018. The market-implied probability of government support for distressed European banks. Working Paper.
Norden, L., Mesquita, D., Wang, W., 2021. COVID-19, Policy interventions and credit: the Brazilian experience. Working Paper.

Norden, L., Roosenboom, P., Wang, T., 2013. The impact of government intervention in banks on corporate borrowers' stock returns. J. Financ. Quant. Anal. 48, 1635-1662.

Norden, L., Udell, G.F., Wang, T., 2020. Do bank bailouts affect the provision of trade credit? J. Corp. Financ. 60, 101522.

OECD, 2021. The COVID-19 Crisis and Banking System Resilience: Simulation of Losses on Non-performing Loans and Policy Implications. OECD, Paris.

Omeokwe, A., 2021. Small-business aid program winds down. Wall Str. J. 1, A4.

Pagano, M.S., Sedunov, J., Veltuis, R., 2021. How did retail investors respond to the COVID-19 pandemic? The effect of Robinhood brokerage customers on market quality. Financ. Res. Lett., 101946

Park, C.-Y., Shin, M.M., 2021. COVID-19, nonperforming loans, and cross-border bank lending. J. Bank. Financ. 133.

Parlatore, C., Philippon, T., 2021. Designing stress scenarios. Working paper.

Peek, J., Rosengren, E.S., 1994. Bank real estate lending and the New England capital crunch. Real Estate Econ. 22, 33-58.

Peek, J., Rosengren, E., 1995. Bank regulation and the credit crunch. J. Bank. Financ. 19, 679-692.

Puddu, S., Waelchli, A., 2015. TARP effect on bank lending behaviour: evidence from the last financial crisis. Working Paper.

Quintyn, M., Taylor, M.W., 2003. Regulatory and supervisory independence and financial stability. CESifo Econ. Stud. 49, 259-294.

Rajan, R.G., 1992. Insiders and outsiders: the choice between informed and arm's-length debt. J. Financ. 47, 1367-1400.

Rajan, R.G., 1994. Why bank credit policies fluctuate: a theory and some evidence. Q. J. Econ. 109, 399-441.

Reinhart, C.M., 2021. The quiet financial crisis. World Bank blog. 〈https://blogs.worldb ank.org/developmenttalk/quiet-financial-crisis .

Reinhart, C.M., Rogoff, K.S., 2009. The aftermath of financial crises. Am. Econ. Rev. 99, 466-472.

Roman, R.A., 2019. Bank bailouts and bail-Ins. In: The Oxford Handbook of Banking.

Sedunov, J., 2021. Federal Reserve intervention and systemic risk during financial crises. J. Bank. Financ. 133.

Semaan, E., Drake, P.P., 2016. TARP and the long-term perception of risk. J. Bank. Financ. 68, 216-235.

Shapiro, J., Skeie, D., 2015. Information management in banking crises. Rev. Financ. Stud. 28, 2322-2363.

Sharpe, S.A., 1990. Asymmetric information, bank lending, and implicit contracts: a stylized model of customer relationships. J. Financ. 45, 1069-1087.

Shleifer, A., Vishny, R.W., 1988. Value maximization and the acquisition process. J. Econ. Perspect. 2, 7-20.

Shrieves, R.E., Dahl, D., 1995. Regulation, recession, and bank lending behavior: the 1990 credit crunch. J. Financ. Serv. Res. 9, 5-30.

Srinivas, V., Byler, D., Wadhwani, R., Ranjan, A., Krishna, V., 2015. Enforcement actions in the banking industry: trends and lessons learned. Deloitte Centre for Financial Services, Deloitte University Press.

Taliaferro, R., 2009. How do banks use bailout money? Optimal capital structure, new equity, and the TARP. Working Paper.

Thakor, A.V., 2005. Do loan commitments cause overlending? J. Money Credit Bank. 37, 1067-1099.

Thakor, A.V., 2015. The financial crisis of 2007-2009: why did it happen and what did we learn? Rev. Corp. Financ. Stud. 4, 155-205.

Thakor, A.V., 2019. A canonical model of disagreement and moral hazard with applications. Working Paper.

Tut, D., 2020. FinTech and the Covid-19 pandemic: evidence from electronic payment systems. Working Paper.

Del Viva, L., Kasanen, E., Saunders, A., Trigeorgis, L., 2017. Bank lottery behavior and regulatory bailouts. Working Paper.

Wagster, J.D., 1999. The Basle Accord of 1988 and the international credit crunch of 1989-1992. J. Financ. Serv. Res. 15, 123-143.

Van Der Weide, M.E., Zhang, J.Y., 2019. Bank capital requirements after the Financial Crisis. In: The Oxford Handbook of Banking.

Wheelock, D.C., Wilson, P.W., 2000. Why do banks disappear? The determinants of US bank failures and acquisitions. Rev. Econ. Stat. 82, 127-138.

Wheelock, D.C., Wilson, P.W., 2005. The contribution of on-site examination ratings to an empirical model of bank failures. Rev. Account. Financ. 4, 110-133. 